MUDALIGE CHAMIKA GAJANAYAKA

\title{
JUDICIAL RECUSAL IN NEW ZEALAND: \\ LOOKING TO PROCEDURE AS THE PRINCIPLED WAY FORWARD
}

LAWS 522: The Judiciary

Submitted for the LLB(Honours) Degree

Faculty of Law

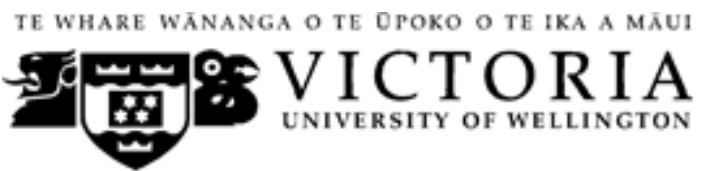

2014 

JUDICIAL RECUSAL IN NEW ZEALAND: LOOKING TO PROCEDURE AS THE PRINCIPLED WAY FORWARD

\section{Table of Contents}

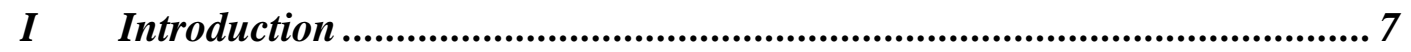

II The Saxmere Saga .......................................................................

III Judicial Recusal in New Zealand: The Current Paradigm ....................... 11

A The Substance of Apparent Bias....................................................... 11

$1 \quad$ The test for apparent bias ........................................................ 11

2 Applying the test for apparent bias .......................................... 12

B Recusal Procedure ................................................................. 14

$1 \quad$ Disclosing an interest ............................................................ 15

2 How is a recusal motion made? ................................................ 15

$3 \quad$ How is a recusal motion dealt with? ......................................... 16

IV The Public Confidence Imperative.............................................................. 17

A Who Is The Public?................................................................. 19

$1 \quad$ The judiciary: an instrument .................................................. 19

2 The judiciary: a service provider ............................................. 20

3 The public: generally ........................................................... 21

B What Fosters the Public's Confidence in the Judiciary? .................... 21

$1 \quad$ Dispute settlement from a judge's perspective ........................... 22

2 Dispute settlement from the public's perspective ....................... 22

V Adjudication: A Process-based Perspective.............................................. 23

A Litigants Initiating Disputes........................................................ 24

B An Adversarial System of Presenting Disputes .................................. 25

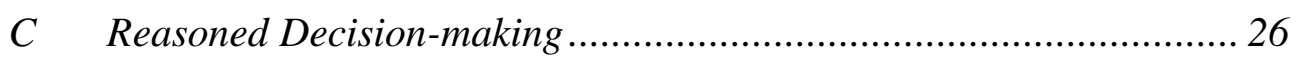

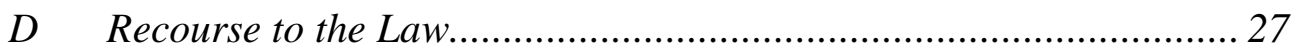

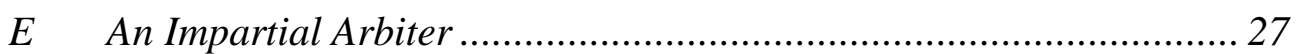

F Process-based Adjudication: Generally ........................................... 29

VI Judicial Recusal: A Mismatch between Theory and Practice .................... 29

A Impediments to Litigants Initiating Recusal Motions ......................... 30

B A Lack of Adversarial Procedure ……............................................. 30

C A Dearth of Reasoned Decisions and Precedent ................................ 31

$D \quad$ The Archetypical Interested Arbiter ................................................. 31

E The Shortcomings of Current Judicial Recusal Procedure................. 32

VII A Way Forward: Procedural Reform ....................................................... 32 
JUDICIAL RECUSAL IN NEW ZEALAND: LOOKING TO PROCEDURE AS THE PRINCIPLED WAY FORWARD

A Disclosure and Filing Recusal Motions......................................... 33

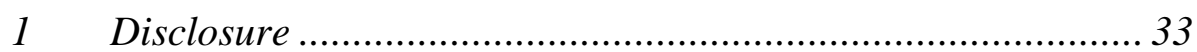

$2 \quad$ Process of questioning an interest and filing a recusal motion 34

B An Impartial Arbiter ........................................................................ 35

C Positive Externalities of an Independent Judge: Adversary; Reasoned Decisions; and Precedent ................................................... 37

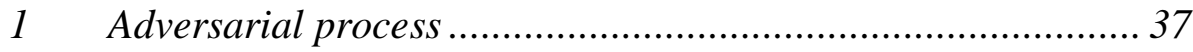

$2 \quad$ Reasoned decisions generating precedent ............................. 37

VIII Procedural Reform: A Critique ............................................................. 37

A Concerns with Transferring Recusal Motions to an Independent Judge .............................................................................. 37

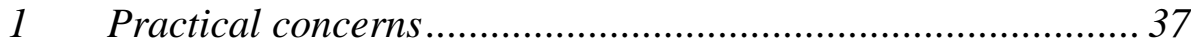

2 Principled concerns .......................................................... 38

B Alterations to the Proposed Reform ............................................... 39

$1 \quad$ When should a recusal motion be transferred to an independent

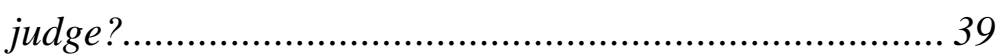

2 Procedural posturing ........................................................... 40

$3 \quad$ Peremptory recusal.......................................................... 40

C Focus on Substance Rather than Procedure ..................................... 41

D Reform: A Solution in Search of a Problem? .................................... 43

IX Saxmere Revisited, Following Reform ................................................. 43

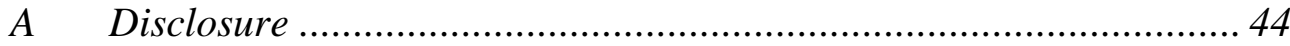

B Filing a Recusal Motion.............................................................. 45

C An Independent Judge and its Corollary Benefits .......................... 45

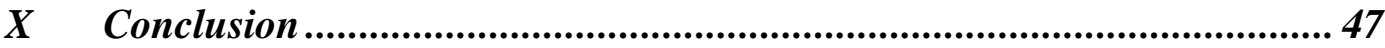

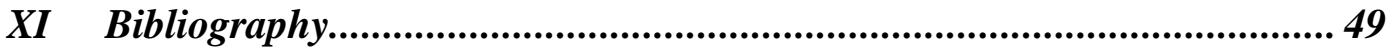


JUDICIAL RECUSAL IN NEW ZEALAND: LOOKING TO PROCEDURE AS THE PRINCIPLED WAY FORWARD

\section{Abstract}

The well-documented Wool Board Disestablishment Co v Saxmere Co litigation thrust the often dormant issue of conflicts of interest between a judge and a litigant into the limelight. Now that the dust has settled on the controversy that culminated in Wilson J's resignation, it is pertinent to question the status quo and investigate the potential cause of the events and, more importantly, whether measures need to be taken to prevent another such occurrence.

This paper takes a principled approach to analysing judicial recusal law in New Zealand, with a particular focus on procedure. In doing so, a mismatch between process theory and the reality of haphazard self-regulation highlights the procedural shortcomings of the current recusal paradigm. To remedy this, the author applies aspects of process theory to reform judicial recusal procedure and bring it in line with general civil litigation practice. The proposed reform instils some fundamental practices that are presently absent in recusal procedure. To contextualise the paper's findings, the author revisits the Saxmere saga to first posit that a lack of procedural safeguards may have contributed to the saga and two, to suggest that had the procedural safeguards proposed by this paper been in place, the controversy could have been mitigated, if not avoided.

Judicial Recusal - Procedural Reform - Process

\section{Word Count}

The text of this paper (excluding title page, table of contents, abstract, footnotes and bibliography) comprises approximately 14,400 words. 



\section{Introduction}

"Whoever has the legislative or supreme power in any commonwealth ... is bound to govern by established standing laws, promulgated and known to the people (and not by on-the-spot decrees), with unbiased and upright judges appointed to apply those laws in deciding controversies."1

John Locke's seventeenth century articulation of the need to resolve "legal disputes by impartial and independent judges is recognised as an essential underpinning of western society". ${ }^{2}$ The United Nations' Universal Declaration of Human Rights affirms that "everyone is entitled in full equality to a fair and public hearing by an independent and impartial tribunal". ${ }^{3}$ In New Zealand, an independent arbiter is a fundamental freedom affirmed by the Bill of Rights Act $1990 .{ }^{4}$ Judges are reminded of the importance of adjudicating impartially upon entering the bench. The judicial oath proclaims that judges must "do right to all manner of people after the laws and usages of New Zealand without fear or favour, affection or ill will". 5

To be impartial, one must be detached and disinterested so that one's personal views and interests do not weigh in on the matter at hand. Recusal is the means by which judicial impartiality is addressed and maintained. ${ }^{6}$ In accordance with Lord Hewart CJ's well-cited dictum that "it is not merely of some importance but is of fundamental importance that justice should not only be done, but should manifestly and undoubtedly be seen to be done", ${ }^{7}$ judges must not only be impartial, they must appear to be impartial. If a judge does not - or notably, if a judge appears to not - bring an impartial mind to adjudicating a dispute, litigants may endeavour to have the judge recused. Alternatively, a judge may recuse themselves sua sponte if they acknowledge that their impartiality may be, or may appear to be, compromised. While easily preached and often assumed, judicial impartiality, and in particular the method of ensuring it, can be difficult to understand.

\footnotetext{
${ }^{1}$ John Locke Second Treatise of Government (Awnsham Churchill, 1690).

${ }^{2}$ Muir v Commissioner of Inland Revenue [2007] NZCA 334, [2007] 3 NZLR 495 at [32].

${ }^{3}$ The Universal Declaration of Human Rights, GA Res 217A, III UN GAOR A/810 (1948) 10.

${ }^{4}$ Bill of Rights Act 1990, ss 25 and 27. Section 25(a) affirms the right to a fair and public hearing by an independent and impartial court in matters of criminal law. Section 27 affirms the right to observe the principles of natural justice, which Hammond J finds to "undoubtedly [encompass] ... the proposition that judges must be independent and impartial" in Muir v Commissioner of Inland Revenue, above n 2, at [32]. ${ }_{6}^{5}$ Oaths and Declarations Act 1957, s 18.

6 Throughout this paper, judicial recusal and judicial disqualification will be conflated and used interchangeably. Strictly speaking, there is a technical distinction between the two terms; disqualification usually reflects a legal requirement for a judge to not sit on a case, for instance due to a per se rule of financial interest with a party, whereas recusal usually reflects a judge deciding to not sit on a case sua sponte.

${ }^{7} R v$ Sussex Justices, ex parte McCarthy [1924] 1 KB 256 at 259.
} 
As Professor Charles Geyh observed, "the legal establishment is deeply divided over when it is reasonable for the presumption of impartiality to yield to the suspicion that extra-legal influences may have compromised the judge's impartial judgment". ${ }^{8}$

This paper critiques judicial recusal law in New Zealand. ${ }^{9}$ Its analysis also has international application as some of the substantive law and many of the processes are prevalent in other common law jurisdictions. New Zealand's current Chief Justice, Sian Elias CJ, articulated in a recent speech that "today respect for courts - without which the rule of law is in trouble - has to be earned and re-earned by doing and the doing has to be painstakingly courteous and reasoned". ${ }^{10}$ The Chief Justice's remarks provide some relevance to this paper's inquiry by posing the question: is judicial recusal law effective in earning the public's respect for New Zealand's courts?

The significance of this paper's inquiry is heightened by recent events that culminated in New Zealand's first and only judicial resignation amidst allegations of an appearance of partiality; the resignation of Wilson J (the Saxmere saga). The author hypothesises that the current recusal paradigm is inadequate to fulfil its principle role of helping to maintain an appearance of judicial impartiality. Further, the author opines that an absence of procedural safeguards may have contributed to the Saxmere saga. And conversely, that had procedural safeguards been in place, the controversy may have been mitigated, if not avoided.

This paper will first summarise the well-documented Saxmere saga to contextualise the ensuing discussion of law, principles and reform. The critique begins with an overview of the substantive law and procedure of judicial recusal in New Zealand. Thereafter, this paper will turn to first principles in looking at how the judiciary is legitimatised. In doing so, public confidence is found to be one of the key legitimising traits of the judiciary with procedural fairness being a primary driver of the public's confidence. The main adjudicatory practices that bolster the public's perceptions of procedural fairness will then be analysed in New Zealand's civil litigation environment.

\footnotetext{
${ }^{8}$ Charles G Geyh "Why Judicial Disqualification Matters. Again" (2011) 30 The Review of Litigation 671 at 676.

${ }^{9}$ The paper focuses its analysis on the High Court and the two appellate courts in New Zealand, the Court of Appeal and the Supreme Court. Further, the paper concentrates on judicial recusal at first instance, rather than on substantive appeals to higher courts based on grounds of partiality or an incorrectly adjudicated recusal motion. Research from overseas jurisdiction, such as the United States, are referred to at times to provide some psychological research and examples. While acknowledging that the law in New Zealand materially differs from that in the United States, the underlying procedures relating to judicial recusal are similar. This is also a reflection on the relative dearth of New Zealand-centric scholarship on judicial recusal.

${ }^{10}$ Sian Elias, Chief Justice of New Zealand "Contemporary Issues for Courts - Demystifying the Judicial Process" (Conference of Chief Justices of Asia and Pacific 2013, Supreme Court, Singapore, 29 October, 2013).
} 
Existing judicial recusal procedures will be compared and contrasted with best-practice adjudication to find that they are deficient and out of line with civil litigation practices in New Zealand. This paper then proposes a number of principled procedural reforms to realign recusal with the civil litigation process. The proposals will be critiqued before finally returning to the Saxmere saga to highlight some of the procedural shortcomings that may have caused the controversy and to personify the proposed reform by hypothetically applying the procedural reform to the Saxmere saga. In doing so, the author postulates that procedural reform holds considerable promise as the way forward for judicial recusal in New Zealand and indeed other common law jurisdictions.

\section{The Saxmere Saga}

The events that culminated in Wilson J's resignation are summarised below. ${ }^{11}$ They are intended to provide some context for the analysis to follow before being revisited in Part IX to compare and contrast New Zealand's current judicial recusal law with this paper's proposed procedural reforms.

Justice Wilson, ${ }^{12}$ then a Judge of the Court of Appeal, was appointed to sit on a case between the Wool Board and Saxmere. ${ }^{13}$ Counsel for the appellant, the Wool Board, was Alan Galbraith QC. Justice Wilson and Galbraith were good friends from their time practicing together at the bar. The two were also business partners in a horse stud, Rich Hill. ${ }^{14}$ In acknowledging the materiality of his business relationship with Galbraith, Wilson J privately telephoned opposing counsel, Francis Cooke QC, to inform him of their mutual business interest. The details of Wilson J's disclosure to Cooke is unclear but it seems to have been distinctly general. ${ }^{15}$ On the basis of the information Wilson $\mathrm{J}$ disclosed in the phone call and after consulting with his instructing solicitors, Cooke informed the Registrar of the court that the respondents had no objection to Wilson $\mathrm{J}$

\footnotetext{
${ }^{11}$ See: Judicial Conduct Commissioner Decision of the Judicial Conduct Commissioner as to Three Complaints Concerning Justice Wilson (7 May 2010) at [34] for a detailed account of the events.

${ }^{12}$ WM Wilson QC is no longer a Judge of the High Court of New Zealand following his resignation from office in 2010. However, for ease, he will be referred to as Wilson $\mathrm{J}$ in this paper.

${ }^{13}$ Wool Board Disestablishment Co v Saxmere Co [2007] NZCA 349, [2007] BCL 885 [Saxmere No 1]. For ease, the respondents, which include four parties, will be referred to as Saxmere throughout the paper. ${ }^{14}$ Gerard McCoy "Judicial Recusal in New Zealand" in HP Lee Judiciaries in Comparative Perspective (Cambridge University Press, 2011) 322 at 330: "[Rich Hill] was a really significant enterprise with revenue in the millions of dollars and it owned livestock and land". Nicky Hager "Appeal Court Judge Faces a Question of Judgement" The Sunday Star Times (New Zealand, 24 August 2008): the business is "worth tens of millions of dollars".

${ }^{15}$ Saxmere Co v Wool Board Disestablishment Co [2009] NZSC 72, [2010] 1 NZLR 35 at [17] [Saxmere No 2]. Judicial Conduct Commissioner, above n 11, at [34].
} 
sitting on the appeal. The case duly proceeded and the court upheld the Wool Board's appeal.

Subsequent to the case, Saxmere discovered that the business relationship between Wilson J and Galbraith was substantially greater that it had thought. On the basis that Wilson $\mathbf{J}$ had not disclosed the extent of his business relationship with Galbraith, Saxmere appealed to the Supreme Court to have the Court of Appeal's judgment set aside. ${ }^{16}$ Prior to the hearing of the appeal, Wilson $\mathrm{J}$ accepted an invitation to further disclose the nature of his business relationship with Galbraith to the Supreme Court. In hearing the appeal, the court concluded that there was no evidence that Wilson $\mathrm{J}$ was "beholden to Mr Galbraith because of the business dimension of their relationship". ${ }^{17}$ Thus, the business relationship was found not to give rise to a reasonable apprehension of bias and the appeal was dismissed.

The Supreme Court's finding of no evidence that Wilson $\mathrm{J}$ had been indebted or otherwise beholden to Galbraith turned out to be crucial. ${ }^{18}$ Saxmere applied to the Supreme Court to recall its judgment on the basis that key points regarding the business relationship had been overlooked or not disclosed. ${ }^{19}$ Wilson J responded to the Supreme Court's request for further disclosure. It transpired that Wilson J had omitted several key facts that had led to the Supreme Court assessing Rich Hill as a "passive" 20 company that Wilson J and Galbraith made "equal contributions"21 to. In fact, when Saxmere No 1 was heard in the Court of Appeal, Wilson $\mathbf{J}$ was indebted to Galbraith due to unequal contributions by the shareholders in anticipation of an investment by the company. ${ }^{22}$ In light of these new facts, the Supreme Court recalled its earlier decision and allowed Saxmere's appeal to set aside the Court of Appeal's judgment and undertake a retrial.

Following several complaints to the Judicial Conduct Commissioner, a Judicial Conduct Panel was appointed to investigate Wilson J's conduct throughout the aforementioned events. Before the Judicial Conduct Panel could deliver its decision, Wilson J resigned. Writing on the saga, Gerard McCoy stated that the Supreme Court's "cachet and prestige ... must have been inadvertently wounded" 23 as a result of the controversy and resignation. This paper does not endeavour to affirm or negate the

\footnotetext{
16 Saxmere No 2, above n 15.

17 Saxmere No 2, above n 15, at [25].

${ }^{18}$ B Robertson "Judicial Ethics" [2010] 121(4) NZLJ 121 at 121.

${ }^{19}$ Saxmere Co $v$ Wool Board Disestablishment Co [2009] NZSC 122, [2010] 1 NZLR 76 [Saxmere No 3].

${ }^{20}$ Saxmere No 3, above n 15, at [15].

${ }^{21}$ Saxmere No 3, above n 15, at [15].

${ }^{22}$ Saxmere No 3, above n 15, at [15]-[16]. Wilson J was indebted to Galbraith by an aggregate sum of over $\$ 242,000$.

${ }^{23} \mathrm{McCoy}$, above n 14, at 335.
} 
accuracy of McCoy's observations. Rather, it is concerned with the law and procedure that left open the possibility for a highly-regarded legal mind to conduct himself in this manner. In Part IX, the Saxmere saga will be revisited to test the author's hypothesis that: one, a lack of procedural safeguards may have contributed to the controversy; and two, that had the procedural reform that is to be proposed in this paper been in place, the controversy could have been mitigated, if not avoided.

\section{Judicial Recusal in New Zealand: The Current Paradigm}

In New Zealand, there is no legislative oversight for assessing the potentially disqualifying nature of a judge's interest with a party or counsel. In this regard, the judiciary is self-regulated. Grant Hammond ${ }^{24}$ described the current framework as: "perched in something of a no-man's land between statutes and common law". ${ }^{25}$ Without looking to confine discussion to particular types of interests that may bring a judge's impartiality into question, this paper will consider apparent bias generally as the catalyst for recusal sua sponte or as the basis for filing a recusal motion by a party. ${ }^{26}$ This Part will set out the test for assessing apparent bias and the procedure for making and handling recusal motions.

\section{A The Substance of Apparent Bias}

\section{The test for apparent bias}

Prior to 2007, the law for establishing apparent bias was "in an awkward state in New Zealand". ${ }^{27}$ This was due in part to earlier conflicting approaches to apparent bias in the United Kingdom and Australia. ${ }^{28}$ Now, notwithstanding "some semantic differences, the test [for apparent bias] in the United Kingdom and Australia have become essentially the

\footnotetext{
${ }^{24}$ In this paper, Grant Hammond is cited both judicially - when he is sitting as a justice of the Court of Appeal - and when he is writing extra-judicially. He will be referred to accordingly.

${ }^{25}$ Grant Hammond Judicial Recusal: Principles, Process and Problems (Hart Publishing, Portland, 2009) at 154.

${ }^{26}$ Hammond, above $\mathrm{n} 25$, at 15 . Traditionally, bias has been categorised into actual bias and apparent bias. Actual bias dealt with a situation where a judge subjectively had "regard to something other than the true merits of the dispute". On the other hand, apparent bias dealt with a situation where it objectively appeared that a judge may have "regard to something other than the true merits of the dispute". The burden of subjectivity required for actual bias made it notoriously difficult, and in fact unnecessary, to establish. Consequently, litigants and courts have focused on apparent bias as the primary situation when a judge should not sit on a case.

${ }^{27}$ Muir v Commissioner of Inland Revenue, above n 2, at [44].

${ }^{28}$ The approach in the United Kingdom in the late twentieth century was articulated by Lord Goff in $R v$ Gough [1993] AC 646 at 670, with the question being: "whether there was a real danger of bias on the part of [the judge]". A year later, Deane J in the High Court of Australia in Webb v R (1994) 181 CLR 41 at 70 stated that the "House of Lords test differs from that accepted in recent cases in this Court" and maintaining that "the fair-minded lay observer" is the standard to be applied in Australia.
} 
same". ${ }^{29}$ The Supreme Court in Saxmere No 2 affirmed the Court of Appeal's approach in Muir to bring New Zealand law in line with the United Kingdom and Australia. ${ }^{30}$ The Supreme Court set out that a judge should recuse themselves: ${ }^{31}$

"if a fair-minded lay observer might reasonably apprehend that the judge might not bring an impartial mind to the resolution of the question the judge is required to decide".

A two stage inquiry is required. ${ }^{32}$ First, "establish the actual circumstances which have a direct bearing on a suggestion that the judge was or may be seen to be biased". ${ }^{33}$ The factual inquiry must be "rigorous" 34 to avoid frivolous or unsubstantiated claims of bias. Second, the fair-minded lay observer is considered in determining whether it would "reasonably apprehend that the judge might not bring an impartial mind to the resolution of the case". ${ }^{35}$ The High Court of Australia emphasised that this "question is one of possibility (real and not remote), not probability" 36 and that "no attempt need be made to inquire into the actual thought processes of the judge". ${ }^{37}$ Nor should there be any consideration as to whether another judge may be better suited to hear a case; the question is wholly directed at the impartiality of the judge in question. ${ }^{38}$

\section{Applying the test for apparent bias}

While there is a wide range of interests that could affect a fair-minded lay observer's perception of a judge's impartiality, Dean J articulated "four distinct, though sometimes overlapping, main categories of [interests that may raise a reasonable apprehension of bias]":39

- having an interest, including a pecuniary and non-pecuniary interest, in a person or entity that is also interested in the case;

\footnotetext{
${ }^{29}$ Saxmere No 2, above n 15, at [3]. In Australia, Ebner v Official Trustee in Bankruptcy (2000) 205 CLR 337 at [6]: the majority of the court set out the test as whether a: "fair-minded lay observer might reasonably apprehend that the judge might not bring an impartial mind to the resolution of the question the judge is required to decide". In the United Kingdom, Porter v Magill [2002] 2 AC 357 at [103] Lord Hope asks: "whether the fair-minded and informed observer, having considered the facts, would conclude that there was a real possibility that the tribunal was biased."

${ }^{30}$ Muir v Commissioner of Inland Revenue, above n 2, at [60]-[64].

${ }^{31}$ Saxmere No 2, above n 15, at [3].

${ }^{32}$ Muir v Commissioner of Inland Revenue, above n 2, at [62].

${ }^{33}$ Muir v Commissioner of Inland Revenue, above n 2, at [62].

${ }^{34}$ Muir v Commissioner of Inland Revenue, above n 2, at [62].

${ }^{35}$ Muir v Commissioner of Inland Revenue, above $\mathrm{n} 2$, at [62].

${ }^{36}$ Ebner v Official Trustee in Bankruptcy (2000) 205 CLR 337 at [7].

${ }^{37}$ Ebner v Official Trustee in Bankruptcy (2000) 205 CLR 337 at [7].

${ }^{38}$ Aussie Airlines Pty Ltd v Australian Airlines Pty Ltd [1996] 65 FCR 215, (2006) 135 ALR 753 at 230231.

${ }^{39}$ Webb $v R$, above $\mathrm{n} 28$, at 74.
} 
- engaging in conduct that leads to an apprehension of bias, either in the course of, or outside the proceedings;

- being associated, either directly or indirectly, with a person or persons interested in the proceedings; and

- obtaining extraneous information, namely prejudicial knowledge that may give rise to an apprehension of bias.

Key to the apparent bias test is the mind of the fair-minded lay observer. In Saxmere No 2, Blanchard J presumed the observer to be: "intelligent and to view matters objectively"; a "non-lawyer but [be] reasonably informed about the workings of our [New Zealand] judicial system"; ${ }^{40}$ and "neither unduly sensitive or suspicious nor complacent about what may influence the judge's decision". ${ }^{41}$ In the House of Lords, Lord Hope classified the observer as one who always reserves judgement and justifies any conclusions objectively. ${ }^{42}$ Commentators have viewed the observer as "a paragon of virtue and so unlike the average member of the public." 43 It is clear that the indeterminacy of applying the fair-minded lay observer can lead reasonable minds to differ when applying the test to a judge's potentially conflicting interest. When considering a recusal issue, judges must also discharge their duty to sit and consider the doctrine of necessity.

\section{(a) Duty to sit}

The judiciary's Guidelines for Judicial Conduct sets out that "judges have an obligation to sit on any case allocated [to them]" 44 and "should not accede too readily to suggestions of bias". ${ }^{45}$ Justice Hammond described the duty to sit as a "counterbalance" 46 that "helps protect judicial independence". ${ }^{47}$ Former Australian Chief Justice Mason CJ more thoroughly emphasised the duty to sit: ${ }^{48}$

"it is equally important that judicial officers discharge their duty to sit and do not, by acceding too readily to suggestions of appearance of bias, encourage parties

\footnotetext{
${ }^{40}$ Saxmere No 2, above n 15, at [5].

${ }^{41}$ Saxmere No 2, above n 15, at [5].

${ }^{42}$ Helow $v$ Secretary of State for the Home Department [2008] 1 WLR 2416 at [1]-[3].

${ }^{43}$ Philip Havers and Alasdair Henderson "Recent Developments (And Problems) In the Law On Bias" (Hart Judicial Review Conference, The Cavendish Conference Centre, London, 10 December 2010) at [9]. Havers and Henderson provide a succinct overview of the fair-minded lay observer at [8]-[18].

44 "Guidelines for Judicial Conduct" (March 2013) Courts of New Zealand <www.courtsofnz.govt.nz> at [27].

45 "Guidelines for Judicial Conduct", above n 44, at [29].

${ }^{46}$ Muir v Commissioner of Inland Revenue, above $\mathrm{n}$ 2, at [35].

${ }^{47}$ Muir v Commissioner of Inland Revenue, above n 2, at [35].

${ }^{48}$ Re JRL; ex parte CJL (1986) 161 CLR 342 at 352. Chief Justice Mason is referring to "judge-shopping" here which is the idea that litigants may seek to have their case heard by a particular judge on the basis that they may adjudicate more favourably to them.
} 
to believe that by seeking the disqualification of a judge, they will have their case tried by someone thought to be more likely to decide the case in their favour."

An apolitical judicial appointment process and relatively neutral extrajudicial utterances suggest that "judge-shopping" is not as live an issue in New Zealand as it may be in other jurisdictions. Nonetheless, the weight judges give to their duty to sit is not universal. Geyh observed that "judges of a more traditionalist bent will guard the presumption of impartiality far more zealously than those with ... more 'realist' learnings". ${ }^{49}$ Traditionalistic views are a hangover from William Blackstone's near irrefutable presumption of judicial impartiality based on the idea that judges could strictly follow the law whilst disassociating themselves from any extra-legal influences. ${ }^{50}$ The realist approach more readily acknowledges that judges may be subject to extra-legal pressures. Additionally, the duty to sit may be stronger in appellate courts due to the limited number of judges that may be available to replace a judge if they decide not to sit.

if a judge recuses themselves.

(b) Necessity

There may be instances where, in the interests of justice, a judge has to sit on a case even when doing so would invoke an appearance of partiality in the mind of a fair-minded lay observer. The necessity doctrine is required on the basis that litigation cannot be non sequitur. ${ }^{51}$ Circumstances where necessity may be invoked are limited. The classical example is where a matter concerns the judiciary as a whole, such as questions of judicial remuneration. In New Zealand, the necessity doctrine is almost non-existent because its appellate courts, the Court of Appeal and Supreme Court, have robust procedures to call upon judges temporarily when a full quorum comprising their permanent judges is not possible. $^{52}$

\section{B Recusal Procedure}

In Muir, Hammond $\mathbf{J}$ remarked that: "there is little discussion of this [judicial recusal procedure] issue in the cases, but there are some real difficulties in this area". In fact, he

\footnotetext{
${ }^{49}$ Geyh, above $\mathrm{n} 8$, at 698 .

${ }^{50}$ Geyh, above n 8, at 678, n 27.

${ }^{51}$ Hammond, above n 25, at 99: "there cannot be a litigation system in which it is impossible to litigate a given case".

${ }_{52}$ Quorum constitution is primarily an issue in a jurisdiction's highest court because a full court is usually required to sit on a case. If a judge is to not sit, then the quorum will not be fully constituted and jurisdictional issues arise. The issue is not prevalent in New Zealand's highest court, the Supreme Court, because temporary judges can be asked to sit on cases where a permanent member cannot sit. Supreme Court Act 2003, s 23. Section 23(1) states: "the Governor-General may appoint as acting Judges of the Supreme Court retired Judges of the Supreme Court or the Court of Appeal".
} 
conceded extrajudicially that "it is difficult to review the procedural law in the recusal area because by and large there is none." ${ }^{53}$ Judicial self-regulation has led to a distinctly informal and ad hoc basis for parties to question a judge's impartiality.

\section{$1 \quad$ Disclosing an interest}

Clearly, parties require knowledge of a judge's potentially disqualifying interest before a recusal motion can be made. Otherwise, parties may not be aware of, nor may they have cause to inquire into, a judge's interests. The Judicial Conduct Guidelines prescribe that judges should make "as early as possible ... in writing and through the Registrar of the Court to counsel for all parties". ${ }^{54}$ The level of disclosure "should ensure that the parties have sufficient information, without unnecessary detail, to decide whether to make a recusal motion". ${ }^{55}$ There may also be instances where a party is aware of intricacies regarding a disclosed interest that a judge is unaware of. If so, counsel should disclose the supplementary information through the Registrar of the court. ${ }^{56}$ Litigants are however not permitted to question a judge in search of potentially disqualifying interest; disclosure is a judge's duty and burden. As Blanchard J observed: ${ }^{57}$

"it is for a judge who makes a disclosure to ensure that the parties have enough information, shorn of unnecessary detail, to make up their minds about whether to make a recusal application. They and their counsel should not be placed in the embarrassing position of having to seek further information from the judge."

\section{$2 \quad$ How is a recusal motion made?}

The appropriate procedure for raising issues of partiality and filing a recusal motion is unclear. One commentator recognised that "there is no uniform practice as to the means by which an objection [to a judge sitting on a case] may be raised". ${ }^{58}$ At first instance, a party question a judge about a potentially disqualifying interest in chambers with counsel for all parties present or in open court through the court's Registrar. ${ }^{59}$ If the judge is not of the view that the interest warrants recusal and so continues to sit, a party may further pursue the matter by filing an originating application supported by affidavits. A judge

\footnotetext{
${ }^{53}$ Hammond, above n 25, at 81.

54 "Guidelines for Judicial Conduct", above n 44, at [42].

55 "Guidelines for Judicial Conduct", above n 44, at [42].

56 "Guidelines for Judicial Conduct", above n 44, at [42]; and "Court of Appeal Recusal Guidelines" (June 2013) Courts of New Zealand <www.courtsofnz.govt.nz> at 2(d).

57 Saxmere No 2, above n 15, at [34]. Litigants cannot "fish" for potentially disqualifying interests.

58 Melissa A Perry "Disqualification of Judges: Practice and Procedure - Discussion Paper" (Victoria, Australian Institute of Judicial Administration, 2001) at [2.29]. For an exposition of the varied circumstances that recusal motions may be made, see: Perry, above $\mathrm{n} 58$, at [2.29].

${ }^{59}$ Hammond, above n 25, at 81.
} 
will then be required to formally respond. Questions of partiality may arise at different stages of the proceedings. ${ }^{60}$ If a party is fully aware of a judge's potentially disqualifying interest throughout a proceeding but fails to raise concerns about it or does not file an originating application in a timely manner, that party will be deemed to have provided fully informed consent for the judge to sit on the case and no subsequent appeals can be made on the basis of partiality. In effect, this is an implied waiver by parties to forego considerations of an appearance of bias. ${ }^{61}$

\section{$3 \quad$ How is a recusal motion dealt with?}

The practice amongst the majority of common law jurisdictions, including New Zealand, is for the challenged judge to determine recusal motions made against them. ${ }^{62}$ Judicial conduct guidelines reinforce this practice. In New Zealand, the Guidelines for Judicial Conduct state that "the question of disqualification is for the judge." ${ }^{63}$ Similarly, the Australian Guide to Judicial Conduct states that "if a judge considers that disqualification is required, the judge should so decide" 64 and that "disqualification is for the judge to decide". ${ }^{65}$ Even in appellate courts where a panel of judges sit, the recusal decision remains with the challenged judge. Judges may consult a potentially conflicting interest with other judges. The Court of Appeal Recusal Guidelines state that "where the issue is not clear cut, the judge should consult ... with other members on the". ${ }^{66}$

A judge may, in light of prior knowledge of an interest between themselves and the parties, choose to recuse themselves sua sponte even before being listed to sit on a case. The Court of Appeal Recusal Guidelines recognise the convenience of prophylactic recusals by allowing a judge to "indicate cases on which they should not be listed, for conflict reasons". ${ }^{67}$ However, ex ante recusals can be impractical in trial courts where judges may be listed to sit on a case with short notice. In the Court of Appeal and the Supreme Court, it is more tenable for a judge to recuse themselves prior to being listed on a case due to sufficient temporal gaps between the filing and hearing of a case.

\footnotetext{
${ }^{60}$ Perry, above $\mathrm{n} 58$, at [1.14]. Perry sets out different stages of the proceedings at which a recusal issue may arise: "at the interlocutory stage, during the course of the trial, during summing up to a jury or in the course of sentencing remarks, after judgment has been reserve, upon delivery of judgment by reason of statements in the judge's reasons, or on appeal."

${ }^{61}$ Saxmere No 2, above n 15, at [36].

${ }^{62}$ Hammond, above n 1, at 148. For examples see: "Guidelines for Judicial Conduct", above n 44, at [29]; and "Court of Appeal Recusal Guidelines", above n 56.

63 "Guidelines for Judicial Conduct", above n 44, at [29].

${ }^{64}$ The Council of Chief Justices of Australia "Guide to Judicial Conduct" (March 2007) Supreme Court of Western Australia <www.supremecourt.wa.gov.au> at [3.5]. New Zealand's Chief Justice is a part of the Council of Chief Justices of Australia.

65 The Council of Chief Justices of Australia "Guide to Judicial Conduct" at [3.5].

66 "Court of Appeal Recusal Guidelines", above n 56, at [2(c)].

67 "Court of Appeal Recusal Guidelines", above n 56, at 2(a).
} 
As alluded to, conflict of interest issues may be dealt with in chambers between the parties and the challenged judge. If an originating application is subsequently made, it should be dealt with immediately in open court to minimise any wasted litigation if a judge decides to recuse him or herself. The judge will announce his or her decision via a Minute. A judge is not required to provide reasons for upholding or dismissing an application. A judge's decision to dismiss a recusal motion can form the basis of an appeal against a judgment. ${ }^{68}$ Alternatively, a litigant may make a similar complaint to the Judicial Conduct Commissioner, whose decisions are subject to judicial review. ${ }^{69}$

Justice Mellissa Perry of the Federal Court of Australia stated extra-judicially that the apparent ease by which parties can raise questions of a judge's impartiality "masks the complex and difficult issues which impact upon the adjectival aspects of disqualification in the courts". ${ }^{70}$ The informality generates a lack of clarity in judicial recusal procedure that is unique when compared to other aspects of the litigation process. The existing judicial recusal procedure will later be compared and contrasted to certain aspects of civil litigation procedure in New Zealand.

\section{The Public Confidence Imperative}

The judiciary is unlike the other two branches of government, the executive and the legislature, in that its legitimacy is not conditional upon the approval of a constituency. It is not exposed to the direct public accountability that the legislature and executive are subject to by way of an electorate's democratic rights. The separation of powers doctrine also protects the judiciary from indirect public accountability to the legislature and executive by virtue of security of tenure ${ }^{71}$ and financial security. ${ }^{72}$ Without a constituent mandate or public accountability, the judiciary's institutional legitimacy must originate from elsewhere. Notwithstanding its lack of public accountability, Hammond identified public confidence as a source of the judiciary's legitimacy when he stated that: ${ }^{73}$

\footnotetext{
${ }^{68}$ Hammond, above n 25, at 101.

69 The Judicial Conduct Commissioner was established by the Judicial Conduct Commissioner and Judicial Conduct Panel Act 2004. The purpose of the Act, set out in s 4, was to "enhance public public confidence in, and to protect the impartiality and integrity of, the judicial system", s 4. In dealing with complaints, the Judicial Conduct Commissioner may: undertake no further action in respect of the complaint, s 15A; dismiss the complaint, s 16; refer the complaint to the Head of the Bench, s 17; or recommend that the judge complained of be removed, s 18. For example: Wilson v Attorney-General [2011] 1 NZLR 399; and Muir v Judicial Conduct Commissioner [2013] NZHC 3507.

${ }^{70}$ Perry, above n 58, at [1.11].

${ }^{71}$ Constitution Act 1986, s 23.

72 Constitution Act 1986, s 24.

${ }^{73}$ Hammond, above n 25, at 5.
} 
"society rightly looks to the courts as bastions of the Rule of Law. If the public cannot look with confidence to judges ... the very notion of a 'legal system' as a fundamental pillar of western society would collapse."

Philip Joseph, a prominent New Zealand constitutional and public law commentator, recognised the importance of public confidence for the judiciary when he stressed that "justice must be rooted in confidence". ${ }^{74}$ Without public confidence, disgruntled members of society may attempt to resolve disputes themselves, which in turn could compromise the Rule of law. ${ }^{75}$ While this paper will focus on public confidence, it is not the only trait that legitimises the judiciary. Judicial independence from legislative, executive and public pressures is also recognised as an "unalterable" fundamental of the judiciary. ${ }^{76}$

Joseph, in finding that "confidence is destroyed when right-minded people go away thinking 'the judge was biased',"77 concluded that "impartiality represents the ultimate value associated with adjudication." ${ }^{78}$ Judges have also recognised the importance of impartiality. For example, when outlining the advantages of the apparent bias test in Saxmere No 2, McGrath J highlighted that that test "gives significant weight to the need for public confidence in the integrity of the judicial system". ${ }^{79}$ Thus, judicial impartiality - and what is more, the appearance of judicial impartiality - seems to be one of the primary means of promoting public confidence. ${ }^{80}$ And so, judicial recusal law, with its purpose being to ensure that dispute are decided by impartial judges, as well as appearing to be decided by impartial judges, inherently serves to protect public confidence. In order to analyse whether the current judicial recusal paradigm is sufficiently robust to help legitimise the judiciary, it is pertinent to further articulate the public confidence imperative. To do so, this Part will address two fundamental aspects of public confidence: first, identify who the public is to understand whose confidence, or lack thereof, may affect the judiciary's legitimacy; and second, how the public's confidence is attained and maintained.

\footnotetext{
${ }^{74}$ Philip A Joseph Constitutional and Administrative Law in New Zealand (4th ed, Brookers, Wellington, 2014) at 797. Here, Joseph is quoting Metropolitan Properties Co (FGC) v Lannon [1969] 1 QB 577 (CA) at 599.

75 For example: Tom R Tyler "The Role of Perceived Injustice in Defendants' Evaluations of Their Courtroom Experience" (1984) 18(1) Law \& Society Review 51 at 51-52: "a lack of public support leads to a willingness to disobey the law and to engage in anti-system behaviours such as riots."

${ }^{76}$ Robin Cooke "Fundamentals" (1988) NZLJ 158 at 164.

77 Joseph, above n 74, at 797. Here, Joseph is quoting Metropolitan Properties Co (FGC) v Lannon [1969]

1 QB 577 (CA) at 599.

78 Joseph, above n 74, at 798 .

${ }^{79}$ Saxmere No 2, above n 15, at [92].

${ }^{80} \mathrm{Joseph}$, above n 74, at 797.
} 


\section{A Who Is The Public?}

In conceptualising whose confidence, or lack thereof, may affect the public's confidence in the judiciary, it is useful to consider whose confidence, or lack thereof, may not affect the public's confidence in the judiciary. Defining the public as the electorate would be misleading because, as alluded to earlier, the judiciary is not accountable to constituents in the way the executive and legislature are. ${ }^{81}$ Nor should the media represent the public because the judiciary is not answerable to the media; it does not respond to media criticism of its performance. ${ }^{82}$ Other representative bodies, such as the New Zealand Law Society, are left to respond to any such criticism as they see fit. To conceptualise the public in either of these ways may inadvertently marginalise the Rule of law by encouraging the judiciary to rule according to popular public sentiment, rather than established legal rules. It is useful to look at the judiciary's functions as the basis for conceptualising who the public is.

\section{$1 \quad$ The judiciary: an instrument}

The judiciary may be viewed as an instrument whose role is to maintain society's right to justice by adjudicating disputes in a just manner. It has been noted that the judiciary is not democratically accountable. Reflecting judicial independence, nor is the judiciary accountable to the executive and legislature. However, the prevailing lack of direct democratic or institutional accountability may not be static. If the public's confidence in the judiciary materially decreases due to a perception that the judiciary is not carrying out its instrumental purpose of maintaining society's right to justice, the public may attempt to influence the judiciary via the legislature. ${ }^{83}$ Subjecting the judiciary to politicking is a more prevalent concern in jurisdictions like the United States where the judicial appointment process is less apolitical and judges have the ability to strike down unconstitutional legislation. In New Zealand, judges are independently appointed and judicial power is more constrained, which suggests that the possibility of the legislature interfering with the judiciary is relatively low.

In saying that, it is not inconceivable for the independence of the New Zealand judiciary to be marginalised following a loss of public confidence. For example, judicial sentencing is one area where political pressure on the judiciary is increasing. Recent efforts by bodies like the Sensible Sentencing Trust have sought to limit judicial discretion and increase legislative prescription in criminal sentencing due to public

\footnotetext{
${ }^{81}$ Geyh, above n 8, at 721-727.

${ }^{82}$ Geyh, above $n$, at $721-727$.

${ }^{83}$ Geyh, above n 8, at 725 .
} 
sentiment that punitive sentences were not sufficiently deterring repeat offending. Its lobbying influenced a change in sentencing law with the enactment of the Sentencing and Parole Reform Act $2010 .^{84}$

The notion that the judiciary's instrumental role is to maintain societal justice is a strong one. Conceptualising the public from this perspective can lead to different definitions of the public. Geyh observed that from an instrumental perspective, the judiciary may primarily be concerned about the confidence of those that are "engaged enough to act upon its dissatisfaction [of the court's instrumental performance]". ${ }^{85}$ While acknowledging that perhaps there is a minority in New Zealand that may look to the legislature to influence the judiciary, this paper opines that this an insignificant minority and that a significant portion of the public would be necessary to influence the judiciary via the legislature. In conceptualising the public from the judiciary's instrumental function, the author postulates a much wider definition of the public. This thought is based on the idea that societal justice affects all of society and so the judiciary's legitimacy may be affected by the confidence, or lack thereof, of any member of society, albeit to a greater or lesser extent, rather than simply those that are sufficiently engaged to actively act upon their dissatisfaction. Thus, the public from an instrumental perspective should be defined as a jurisdiction's whole society, both individually and collectively.

The judiciary: a service provider

The judiciary may prima facie be viewed as a state-sponsored dispute resolution service to society. Naturally, the primary focus of any service provider is likely to be its customers and ensuring that they are satisfied with the service so that they will return for repeat custom. Adopting this notion, the "customers" of the judiciary are the litigants that appear before the court. ${ }^{86}$ Litigants are whom the bench and bar alike have direct influence over. However, confining the judiciary's customers and influence as narrowly as this may be misleading. Simon Shetreet stated that "at one time courts were viewed merely as a dispute resolution institution ... [but] today it is widely recognised that the judiciary performs the function of law making. ${ }^{87}$ This suggests that in resolving disputes, the judiciary is undertaking a de facto law-making function. Per the Rule of law, law affects every member of society. Thus, if it can be said that the judiciary has a surrogate law-making function, notwithstanding it is subject to parliament's sovereignty,

\footnotetext{
${ }^{84}$ Sentencing and Parole Reform Act 2010, s 3(b): the Act's purpose is to "impose maximum terms of imprisonment on persistent repeat offenders who continue to serious violent offences." The Act's primary change was to enact the "three-strikes" law for repeat offenders.

${ }^{85}$ Geyh, above $\mathrm{n} 8$, at 725 .

${ }^{86}$ Geyh, above $\mathrm{n} 8$, at 725 .

${ }^{87}$ Simon Shetreet "Judging in Society: The Changing Role of Courts" in Simon Shetreet The Role of Courts in Society (Martinus Nijhoff Publishers, Dordrecht, 1989) 467 at 467.
} 
its dispute resolution service affects every member of society, not just the litigants that appear before the court. Consequently, the judiciary's customers should not be limited to litigants, but should encompass the jurisdiction's whole society.

\section{The public: generally}

One's perspective of the judiciary's role may affect how one conceptualises the public whose confidence may materially impact upon the judiciary's legitimacy. The foregoing discussion demonstrated that the public can be taken to encompass each and every member of society. The ensuing question is: what fosters the public's confidence in the judiciary?

\section{B What Fosters the Public's Confidence in the Judiciary?}

In adopting a wide view of the public, a wide view of what fosters their confidence may also be required. Judicial impartiality has been recognised as a key driver of the public's confidence in the judiciary. Implicit in this notion is that judicial process is important because impartiality is concerned with how the law is applied to a dispute rather than what the law is.

Researchers at the University of Otago conducted empirical research on public perceptions of the New Zealand court system. ${ }^{88}$ When respondents were asked whether they believed that they "would get a fair hearing in the New Zealand court system", ${ }^{89}$ the mean response was a 2.4 out of 5.0..$^{90}$ This shows that, on average, more respondents perceived the court system as fair than unfair. From a layman's perspective, these findings may seem counterintuitive because one may assume that people who do not win a dispute would be more inclined to perceive the courts negatively, and vice versa, to average out to an even half-and-half perception of fairness. This suggests that a favourable decision may not be the only factor that determines the public's idea of fairness. To better understand what aspects of the court system promote perceptions of fairness, it is useful to compare and contrast the dispute settlement rhetoric between the judiciary and the public.

\footnotetext{
88 Saskia Righarts and Mark Henaghan "Public Perceptions of the New Zealand Court System: An Empirical Approach to Law Reform" (2010) 12(2) Otago Law Review 329.

${ }^{89}$ Righarts and Henaghan, above n 88, at 334.

${ }^{90}$ Righarts and Henaghan, above n 88, at 335: "a 1 represents a 'strongly agree' (a positive response to each question), a 5 represents a 'strongly disagree' (a negative response to each question), and a 3is a neutral response (neither agree or disagree)."
} 


\section{$1 \quad$ Dispute settlement from a judge's perspective}

Judges are decision makers. The public is a decision recipient. Social science research has found that decision makers and decision recipients view dispute settlement differently. When researching the psychology of decision makers and decision recipients, Larry Heuer found that the former pegged their perceptions of fairness to the societal outcomes produced by a decision. ${ }^{91}$ Heuer's findings held when he combined with Diane Sivasubramaniam to investigate the psychology of judges and litigants. ${ }^{92}$ Their research reiterated that judges, akin to decision makers generally, "were more heavily influenced by outcome fairness than by procedural fairness". ${ }^{93}$ Perceiving fairness based on a societally just outcome is also termed distributive justice. Due to a lack of substantive knowledge of the law, it may be difficult for the public to properly assess whether a judge delivered a fair outcome. For example, in the judicial recusal context, judges harbour varying views as to how the fair-minded lay observer test should be applied. If judges cannot come to a consensus on whether the outcome of a recusal motion was fair, it is unrealistic to expect that the public will.

Judicial preoccupation with distributive justice is understandable because judges pride themselves on applying the law accurately. However, in doing so, there is a danger that judges may not adequately consider how the public, as decision recipients, perceive the fairness of dispute settlement.

\section{Dispute settlement from the public's perspective}

While distributive justice is undoubtedly important to the public as it may affect them directly, if not indirectly, it can be difficult to objectively assess; distributive justice to one may be distributive injustice to another. The difficulty is exacerbated when considering that recipients of the judiciary's decisions include each member of society. Significantly - and perhaps as a reflection of the difficulties in assessing distributive justice - social science research has found that people "care more about the fairness of the process that produces the outcome". ${ }^{94}$ In other words, the public place an equal, if not greater, emphasis on procedural justice as they do on distributive justice. This theory originates from John Thibaut and Laurens Walker's seminal social science research that demonstrated people's assessments of the fairness of third-party decision-making

\footnotetext{
${ }^{91}$ Larry Heuer "What's Just About the Criminal Justice System? A Psychological Perspective" (2005) 13 Journal of Law And Policy 209 at 214-218.

${ }^{92}$ Diane Sivasubramaniam and Larry Heuer "Decision Makers and Decision Recipients: Understanding Disparaties in the Meaning of Fairness" (2007) 44(1) Court Review 62 at 65.

${ }^{93}$ Sivasubramaniam and Heuer, above n 92, at 64.

${ }^{94}$ John M Greacen "Social Science Research on 'Procedural Justice': What Are the Implications for Judges and Courts?" (2008) 47(1) The Judge's Journal 41 at 41.
} 
procedures shape their satisfaction with an outcome. ${ }^{95}$ Professor Tom Tyler further confirmed that "it is clear ... citizen assessments of the justice of the procedures used by legal authorities to make decisions influence reactions to those decisions." 96 It also reflects the philosophical importance James White placed on procedure when stating that, "we [the public] are entitled not to 'like results' but to 'like process'." ${ }^{97}$ Four factors have been identified as the primary drivers of people's procedural fairness judgement: "opportunities for participation; the neutrality of the forum; the trustworthiness of the authorities; and the degree to which people receive treatment with dignity and respect". ${ }^{98}$

Applying the procedural justice notion to judicial recusal, litigants and the public are likely to place an equal, if not greater, level of importance on the process by which a recusal motion is adjudicated as they are on its outcome. Therefore, if the process invites participation and appears neutral with a trustworthy judge that treats the participants with respect, litigants and the public alike are more likely to accept the outcome of a recusal motion. Increased procedural satisfaction may thus lead to increased public confidence in the judiciary, which the foregoing discussion suggests may promote its legitimacy. To assess whether judicial recusal law adequately fosters procedural satisfaction in the public, it is helpful to look for guidance from legal process theory. The following Part will set out the fundamental aspects of third-party adjudication that legitimises its outcomes.

\section{Adjudication: A Process-based Perspective}

Litigation is a form of third-party dispute resolution where parties take their disputes to courts for judges to determine an outcome according to relevant law. Professor John Allison finds that "many procedural elements found in judicial and administrative adjudication perform a surrogate legitimation function."99 Allison identified the

\footnotetext{
95 J Thibaut and L Walker Procedural Justice: A Psychological Analysis (Lawrence Erlbaum Associates, 1975). See generally: Greacen, above n 94; and Tom R Tyler "Social Justice: Outcome and Procedure" (2000) 35(2) International Journal of Psychology 117.

96 Tom R Tyler "What is Procedural Justice? Criteria Used by Citizens to Assess the Fairness of Legal Procedures" (1988) 22(1) Law \& Society Review 103 at 104.

97 James Boyd White Heracles' Bow: Essays on the Rhetoric and Poetics of the Law (University of Wisconsin Press, Wisconsin, 1985) at 134.

${ }^{98}$ Tyler, above $\mathrm{n} 96$ ] at 121. At 121-122: participation refers to providing parties "an opportunity to make arguments about what should be done to resolve a problem or conflict"; neutrality refers to parties' beliefs "about the honest, impartiality, and objectivity of the authorities with whom they are dealing"; trustworthiness refers to parties being "concerned about the motivation underlying the decisions made by the authority with whom they are dealing"; andtreatment with dignity and respect refers to parties "having respect shown for their rights".

${ }^{99}$ John R Allison "Ideology, Prejudgment, and Process Values" (1994) 28 New England Law Review 657 at 682 .
} 
procedural elements to generally include: "published rules, party participation, reasoned decisions, and communicated rationales". ${ }^{100}$ He noted that adjudication processes that exhibit these features usually "have the intended and actual effect of enhancing public perceptions of legitimacy." 101 Professor Amanda Frost subsequently looked to Allison and other process theorists to extract "five procedural components of adjudication that are universally considered essential to the legitimacy of the final product [the decision]". ${ }^{102}$ Frost specifically looked to the judicial process when she articulated the components as being:

(1) litigants initiating disputes;

(2) the disputes being presented via an adversarial system where the competing parties articulate their conflicting views;

(3) a reasoned decision should be provided;

(4) decisions must be consistent with the rule of law; and

(5) the arbiter must be impartial.

While New Zealanders do not enjoy an inalienable right to due process like Americans do, proper process is nonetheless a fundamental right protected by the Bill of Rights Act 1990. ${ }^{103}$ This Part will examine Frost's five procedural components and illustrate that they feature prominently throughout New Zealand's litigation process.

\section{A Litigants Initiating Disputes}

Courts do not initiate disputes in New Zealand. They rely on injured parties to bring disputes to them. The courts' passiveness stems from two limitations. First, the courts are fiscally limited to the resources and manpower that the Ministry of Justice affords them. Judges have one or two clerks and the court may have some further research and general administration assistance. This does not leave residual resources available to investigate and commence proceedings. Second, in upholding the doctrine of judicial independence, courts do not have a prerogative from anyone to instigate a dispute. Judges have no constituency from whose needs and wants an agenda can be drawn up. Nor do

\footnotetext{
100 Allison, above n 99, at 682.

101 Allison, above n 99, at 682.

102 Amanda Frost "Keeping Up Appearances: A Process-Oriented Approach to Judicial Recusal" (2005) 53(3) Kansas Law Review 531 at 555-556.

103 There are two due process clauses in the United States Constitution. The fifth amendment to the Constitution guarantees "nor shall any person ... be deprived of life, liberty, or property, without the due process of law." The fourteenth amendment to the Constitution guarantees "nor shall any State deprive any person of life, liberty, or property, without due process of law."
} 
they have the expertise to isolate and address specific societal problems; they are generalists, a virtue that is more or less revered. ${ }^{104}$

It is the responsibility of the executive to bring claims on behalf of the State. It has the capabilities and the mandate to undertake this role. By requiring parties to originate disputes, it engages them in the process from the beginning and increases their feeling of participation - a contributory factor to an appearance of procedural justice factor, as Greacen identified. One commentator stated that "participation clothes the resulting decision with legitimate authority to bind the litigants". ${ }^{105}$ It is standard practice throughout the litigation process for parties to initiate disputes, whether it be a party filing a statement of claim or applying for leave to appeal a decision, it is the plaintiff, prosecution or appellant that commences a dispute.

\section{B An Adversarial System of Presenting Disputes}

The traditional adversarial litigation system enables parties to present their arguments and advocate for their respective claims. Christopher Peters articulated the party-centric adversarial model when stating that "each litigant, not the court itself, locates relevant facts and identifies relevant legal authorities, and each litigant determines whether and how to present those facts and authorities to the court in the form of legal arguments." 106 Frost identified a benefit of this process by analogising that "party control over casepresentation is legitimating for much the same reasons that party control over caseinitiation is legitimating." 107 By putting their case, the litigants' feeling of participation in the proceeding increases, which again contributes to an appearance of procedural justice. The decision maker is also more likely to be better informed if he or she is exposed to the competing views of the parties. Fiscal constraints also render it impractical for courts to undertake an inquisitorial or investigative role here. The judge remains "remains relatively passive" 108 throughout this process and only after the parties have put their case will the judge "render a decision that is responsive to the proofs and arguments made by the litigants". ${ }^{109}$

\footnotetext{
104 The virtues of judicial specialisation is not a debate this paper seeks to partake in. Some view specialisation, particularly in certain areas such as commercial or tax litigation as a positive step.

${ }^{105}$ Christopher J Peters "Adjudication as Representation" (1997) 97(2) Columbia Law Review 312 at 374.

106 Christopher J Peters "Persuasion: A Model of Majoritarianism as Adjudication" (2001) 96(1)

Northwestern Law Review 1 at 20.

${ }^{107}$ Frost, above n 102, at 559.

108 Peters, above n 106, at 21.

${ }^{109}$ Peters, above n 106, at 21 (emphasis added).
} 


\section{Reasoned Decision-making}

Frost recognised that decisions accompanied by logical and coherent reasoning are "a vital source of legitimacy for judicial decision-making". A number of justifications for the reasoned decision imperative will be discussed.

First, as noted, the judiciary's legitimacy does not originate from a democratic mandate. Rather, it is the public's confidence in its function that legitimises the judiciary. A reasoned decision illustrates that the judge has factored in the parties' arguments, which bolsters the appearance of neutrality for litigants to help further their perception of procedural justice. It goes some way in appeasing any concerns a losing party may have about the judge holding prejudicial or arbitrary views that could have materially affected the outcome of the case.

Second, Professor Frederick Schauer clearly expresses the cognitive value in providing reasons for a decision. He stated that a legally, socially or morally impermissible result may arise from legally, socially or morally impermissible reasoning. ${ }^{110}$ Schauer opines that "perhaps there are things we [including judges] can think but cannot write down." 111 If so, one may be able to reason impermissibly if thought alone was one's only constraint. But, when one has to commit to that thought by way of orating it or recording it in prose, a further constraint is added; a constraint that limits one's ability to reason impermissibly. It commits a decision maker to the reasoning that he or she articulates, which is more likely to lead to permissible reasoning due to the possibility of subsequent scrutiny. Accordingly, requiring a judge to provide reasons for a decision imposes a constraint on judicial discretion to adjudicate within a permissible framework that may or may not otherwise be there.

Finally, Schauer raises the interesting proposition that "when we [including judges] provide a reason for a particular decision, we typically provide a rule, principle, standard, norm, or maxim broader than the decision itself". ${ }^{112}$ The decision that the reason produces is just one of a number of factual matrices that could be decided under that enunciated rule. Thus, in conjunction with the said idea of positively constraining thought, reasoned decisions are more likely provide consistency in decision-making. Reasoned decisions are also necessary to enable a party to exercise their right of appeal. Without reasons, it is impractical - and realistically untenable - for a litigant to base an appeal on the simple notion that the trail judge was "wrong". Chief Justice Elias also

\footnotetext{
${ }^{110}$ Frederick Schauer "Giving Reasons" (1995) 47 Stanford Law Review 633 at 652.

${ }^{111}$ Schauer, above n 110, at 652.

${ }^{112}$ Schauer, above n 110, at 641.
} 
highlights the importance of access to decisions in vindicating the judiciary's conduct. ${ }^{113}$ In New Zealand, reasoned judgments are delivered and publicly available for all High Court, Court of Appeal and Supreme Court cases.

\section{Recourse to the Law}

Having recourse to the law in adjudicating a dispute is an uncontroversial constraint on judicial power. ${ }^{114}$ In leading the legal process movement, HLA Hart recognised that "rule by arbitrary choice is not rule by law". ${ }^{115}$ With the law becoming more complex and indeterminate, judicial discretion plays an increasingly material role in decisions. ${ }^{116}$ The neutrality and trustworthiness of a judge is likely to be questioned if he or she exercises this discretion ad hoc without rooting it in the law. The strong emphasis that the common law places on precedent further constrains the judge to resolve like disputes with like decisions. Parties' perceptions of neutrality and trustworthiness will also be enhanced if they are confident that a judge has decided a dispute according to the law.

Outcomes adhering to the rule of law are more likely to provide rational, consistent and predictable decisions. This enables the law to develop logically and in a manner that reflects the changing values of society. Predictability helps guide societal behaviour by providing a distinction between what is legal and what is illegal. Consistent decisions are likely to improve litigants' perceptions of due process because if similar facts produce similar decisions, a litigant would perceive the process by which the decisions was made.

\section{E An Impartial Arbiter}

Arguably the most fundamental facet of any adjudication and litigation process is that disputes are resolved by an impartial arbiter. The whole premise for judicial recusal is founded on an impartiality imperative; if partial judges were accepted, there would be no need for judges to consider not sitting on a case due to a reasonable apprehensions of bias. As Tipping J enunciated in Saxmere No 2, "the rationale for the rule against apparent bias is to ensure that public confidence in the legal system and the impartiality of judges is

\footnotetext{
113 Elias, above n 10, at 5-6.

114 Joseph, above $\mathrm{n} 74$, at 153-199.

115 Geoffrey C Shaw "HLA Hart's Lost Essay: Discretion and the Legal Process School" (2013) 127(2) Harvard Law Review 666 at 668.

116 This notion goes against the traditional legal formalist theory of there always being one answer to a question and so discretion or morals should not play a part in decision-making; decision making is thus purely based on competency and if judges are competent, they should all come to the same outcome on any given dispute. As the law has developed since this articulation, it is now widely regarded as overly simplistic and unrealistic.
} 
maintained." 117 Thus, if litigants - and the public - harbour a reasonable apprehension of bias of a judge, a proceeding's neutrality may be compromised, as well as the parties' trustworthiness of the judge. The effects may also flow on to parties limiting their cooperation and participation in the proceedings and thereby affecting perceptions of procedural justice. An overview of the cognitive difficulties with self-adjudication is useful to illustrate the psychological premise for impartial adjudication.

Common sense suggests that "[a] biased mind rarely realises its own imperfection". ${ }^{118}$ Ironically, the more biased a person may be, the more difficult it is likely to be for them to accurately assess their own biased. Cognitive theory provides a firmer basis for highlighting the inadequacies of self-adjudicating conflicts of interest. Researchers at Stanford University revealed that people, including judges, have a "bias blind spot". ${ }^{119}$ The blind spot refers to an asymmetry in judging one's cognitive susceptibilities vis-à-vis other people's cognitive susceptibilities. ${ }^{120}$ This asymmetry leads to an overoptimistic view of one's competency due to one being unaware of unconscious factors that may affect one's decisions. ${ }^{121}$ In Stanford's research, individuals reported that they were "less susceptible than their peers to various cognitive and motivational biases". ${ }^{122}$

Some may argue that the years of training and experience that judges have in resolving disputes may enable them to exercise superior cognitive abilities of adjudication than the general population. However, regardless of any superior cognitive capability, it is likely judges are susceptible to the same natural biases that all humans may be susceptible to. These biases may range from status quo bias ${ }^{123}$ to overconfidence ${ }^{124}$ and false consensus bias. ${ }^{125}$ Preserving judicial impartiality is prevalent throughout the

\footnotetext{
117 Saxmere No 2, above n 15, at [38].

${ }^{118}$ Note "Disqualification of a Judge on the Ground of Bias" (1927) 41(1) Harvard Law Review 78.

${ }^{119}$ Emily Pronin, Daniel Lin and Lee Ross "The Bias Blind Spot: Perceptions of Bias in Self Versus Others" (2002) 28 Personality and Social Psychology Bulletin 369.

${ }^{120}$ Pronin, Lin and Ross, above n 119, at 374.

${ }^{121}$ Pronin, Lin and Ross, above n 119, at 374.

122 Pronin, Lin and Ross, above n 119, at 374.

123 Jeffrey W Stempel "In Praise of Procedurally Centered Judicial Disqualification - and a Stronger Conception of the Appearance Standard: Better Acknowledging and Adjusting to Cognitive Bias, Spoliation, and Perceptual Realities" (2011) 30(4) The Review of Litigation 733 at 741, n 24: status quo bias is an unconscious tendency to interpret something in a manner that maintains the existing situation. In the recusal context, it could mean that more traditionalistic judges may uphold the strong presumption of impartiality by overemphasizing their duty to sit.

${ }^{124}$ Stempel, above n 123, at 741, n 25: overconfidence, as alluded to earlier, is when people, including judges, tend toward excessive optimism and overconfidence. In the recusal context, this may lead to a judge overemphasising their ability to detach themselves from any underlying interests.

125 Stempel, above n 123, at 741, n 26: false consensus bias arises when a person assumes that everyone else interprets or perceives something the same way as they do, even if it is ambiguous. In the recusal context, a judge may feel that an interest need not be disclosed to the parties because both parties would simply view it as immaterial, as he or she does.
} 
litigation process with parties being able to file recusal motions at any stage of the proceeding, subject to implied waiver, and appeal to have a judgment set aside based on impartiality.

\section{F Process-based Adjudication: Generally}

Although these five key aspects of judicial procedure have been described independently, the majority are interdependent. For example, it will be more difficult for a judge to be partial if a decision must be accompanied by reasoning as the parties and public can scrutinise the reasoning. Moreover, if that decision is subject to precedent, there is even less scope for extra-legal influences to affect an outcome because the case for departing from precedent must be strong. Conversely, it will be difficult to be assured that the judge had sufficient recourse to law if no reasons are provided for their decision. Likewise, if the dispute, the facts and the arguments are solely brought by the parties, it is less likely that a judge's personal agenda or motives can shape the outcome because the dispute must be addressed in the manner that the litigants have put it.

These processes are commonly followed throughout civil litigation in New Zealand and moreover, they are followed throughout the majority of third-party adjudicatory processes. There may be instances, such as interim injunctions, where due process may be marginalised due to temporal urgency, but these instances are few and far between. ${ }^{126}$ Departing from established procedural methods is the exception, not the rule. Individually and collectively, these procedural elements help to legitimise the judiciary's adjudicative role which in turn nurtures the public's confidence in the third branch of government. In light of this, the following Part illustrates the extent to which judicial recusal process strays from these fundamental qualities.

\section{Judicial Recusal: A Mismatch between Theory and Practice}

With the soft and indeterminate nature of existing recusal procedures outlined and five key practices that legitimise adjudication analysed, it is possible to compare and contrast the former with the latter to ascertain whether current recusal procedure follows best practice. This Part will use legal and psychological rhetoric to illustrate the "procedural vacuum" 127 in which judicial recusal operates.

\footnotetext{
${ }^{126}$ In the case of interim injunctions, any marginalisation of proper process is subsequently rectified following a full trial.

${ }^{127}$ Frost, above n 102, at 551.
} 


\section{A Impediments to Litigants Initiating Recusal Motions}

As a result of information asymmetries, the onus is on a judge, rather than a litigant, to raise any potential conflicts of interest. ${ }^{128}$ Prima facie, this does not reconcile well with best practice adjudication because a judge should not initiate a dispute. However, in disclosing an interest, a judge is not necessarily initiating a dispute. Rather, they are merely providing the information of an interest that then may form the basis of a recusal motion; it is still the litigant who raises and disputes an issue with a disclosed interest. Further, the usual concerns of fiscal deficiencies and a lack of mandate are absent in burdening a judge with disclosure; the judge inherently has the knowledge of the interest and need not conduct further research into the interest.

Unlike issuing proceedings, amending statements of claim or submitting interlocutory appeals, there is little guidance as to how a recusal motion can or should be made. The usual method of giving notice is through the Registrar or by filing an originating application. A lack of formality may reasonably conjure some hesitancy in counsel to bring a recusal motion for fear of offending a judge. Richard Flamm analogised questions of legal error with questions of partiality when he observed that "[just] as judges generally do not like to admit having committed legal error, they are typically less than eager to acknowledge the existence of situations that may raise questions about their impartiality." ${ }^{129}$ An understandably conservative approach to filing recusal motions may to ensue. Litigants may be faced with a compromise between fully participating in a proceeding by filing a recusal motion and a consequent lack of judicial neutrality if the motion is dismissed and the judge is annoyed. This is undesirable because litigants should not dissuade themselves from filing recusal motions for fear of subsequent adverse findings by a challenged judge.

\section{B A Lack of Adversarial Procedure}

Conflicts of interest usually arise between a judge and one party. Thus, to align with the adversarial process, a judge should offer their conflicting views when putting their case to the party that has made a recusal motion as to why recusal is not required. However, a judge rarely responds to a recusal motion as a defendant or respondent would respond to a statement of claim due to the judge also being the arbiter of the motion. It goes against common sense and cognitive theory to expect a judge to be able to argue for a particular outcome in a dispute and then be able to impartially adjudicate that very dispute. Without the adversarial forum for all parties to articulate their views, there is a

\footnotetext{
128 "Guidelines for Judicial Conduct", above n 44, at [41]-[45].

${ }^{129}$ Richard E Flamm Judicial Disqualification: Recusal and disqualification of Judges (2nd ed, Banks \& Jordan Law Publishing Co, Berkley, 2007) at 25.
} 
danger that a recusal motion could be decided without the arbiter being exposed to the parties' competing arguments and thus not being fully informed. This may endanger litigants' trust that the judge is doing what is right for them as well as marginalise their participation by not being able to respond to arguments as they would with other parties.

\section{A Dearth of Reasoned Decisions and Precedent}

The majority of recusal decisions provide little insight into the nature of the interest in question, the grounds on which recusal was sought or the judge's rationale in deciding to sit or not to sit. This is especially so when a judge recuses themselves sua sponte before proceedings commence or even before they are listed on a case. Although prophylactic measures to avoid wasted litigation time is preferable, a judge's decision should be subject to scrutiny, as other judicial decisions are. The absence of a decision precludes public scrutiny and cognitive commitment, which may also invite a judge to consider impermissible factors. Professor Jeffrey Stempel recognised the shortage of reasoning when he stated that "the clipped, abrupt, and uninformative manner in which many disqualification decisions are delivered undermines the public confidence the process should inspire". ${ }^{130}$

Precedent plays an important role in guiding judges to an accurate judgment. It is particularly useful when the law is ambiguous, like the fair-minded lay observer test. The upshot of judges providing little to no reasoning for their recusal decisions is that precedents are scarce. Adding to the inadequacy is the inclination for judges to provide more reasons for dismissing a recusal motion than for affirming a recusal motion. ${ }^{131}$ Without reference to precedent, people may more readily perceive a judge to be adjudicating a recusal motion ad hoc rather than by the rule of law.

\section{The Archetypical Interested Arbiter}

A challenged judge self-adjudicating recusal motions is arguably the most glaring deficiency of the current judicial recusal process. The process is often justified by the idea that a challenged judge possesses the most knowledge about the interest in question and thus they are in the best position to assess whether it will appear to affect their impartiality. ${ }^{132}$ This is a flawed proposition that wrongly correlates knowledge with adjudicative ability. ${ }^{133}$ Cognitive theory reinforces the challenges associated with

\footnotetext{
130 Stempel, above n 123 , at 799.

${ }^{131}$ Frost, above n 102, at 570.

${ }^{132}$ Hammond, above $\mathrm{n} 25$, at 83.

${ }^{133}$ Geyh, above $\mathrm{n} 8$, at 708. Geyh articulated the fundamental fallacy of judicial recusal law by stating that: "disqualification practice proceeds on two implicit assumptions: that judges are able to assess the extent of
} 
expecting judges to be able to impartially adjudicate questions of partiality made against them. Throughout the litigation process, a disinterested judge with less intimate factual knowledge than the parties adjudicates the case. While this bolsters the public's perceptions of neutrality, it is difficult to envisage that self-adjudication of recusal motions has the same effect. When commenting on this practice, Hammond concluded that "there is a hopeless tension between the state-fostered guarantee of a neutral and objective arbiter of a case and the state's current process arrangements for disqualification decisions." 134

\section{E The Shortcomings of Current Judicial Recusal Procedure}

Notwithstanding that litigants may be discouraged from questioning a judge's partiality, if a recusal motion is made, an absence of adversarial procedure, reasoned decisionmaking, precedent and an independent arbiter highlights the discrepancies between best practice found in civil litigation and the deficiencies of judicial recusal procedure. The fundamental importance of judicial impartiality in fostering the public's confidence in the judiciary justifies a look at taking a more principled approach to addressing questions of judicial partiality.

\section{A Way Forward: Procedural Reform}

In keeping with this paper's focus on process over substance, the author proposes procedural reform to provide more clarity, certainty and custom for judicial recusal. The following reform is to be imposed by the judiciary, rather than through legislative intervention. As Hammond emphasised, maintaining a separation of powers and judicial independence is vital, particularly in an area like impartiality which goes to the heart of the judiciary's credibility. ${ }^{135}$ To justify a formal regulatory regime, Hammond argued that the judiciary must be "beyond self-redemption". ${ }^{136}$ The author concurs with Hammond in observing that the New Zealand judiciary is not nearing that point. Rather, it has long enjoyed the public's confidence. Thus, reform should come from within the bench, not from the outside.

their own bias; and that judges are able to assess how others reasonably perceive their conduct. Neither assumption is safe."

${ }^{134}$ Hammond, above n 25, at 148.

135 Hammond, above n 25, at 153.

${ }^{136}$ Hammond, above n 25, at 153. 
The adopted processes should be recorded in the Gazette so that the legal profession and the public can be fully aware that the judiciary acknowledges and is actively taking steps to maintain judicial impartiality and preserve public confidence.

\section{A Disclosure and Filing Recusal Motions}

\section{$1 \quad$ Disclosure}

McCoy observed that "the vulnerability of the parties before the court is their dependence on the timeliness, comprehensiveness and reliability of judicial disclosure." ${ }^{137}$ While the New Zealand judiciary's Guidelines for Judicial Conduct provide some useful advice to judges of the importance of disclosure and factors to consider when disclosing an interest, the guidance is somewhat abstract. ${ }^{138}$ A register - similar to that which members of the executive and legislature are subject to - whereby judges would be required to periodically disclose their pecuniary interests to the public has been suggested as a means of improving disclosure and transparency. ${ }^{139}$ This paper does not view public financial disclosure by judges as the way to symmetrise the asymmetry of information between the bench, the bar and the public. Instead, this paper looks to impose greater disclosure obligations on judges to require them to disclose any pecuniary, personal or professional relationships with parties in open court. This does not require a significant change from the status quo, rather it is a hardening and nuancing of the existing duty to disclose.

Currently, judges may withhold information unless, after introspection of the nature of the interest and its proximity to the parties, they perceive the interest to be potentially conflicting. Essentially, this is a negative duty that begins from the basis that a judge is impartial - and thus nothing need be disclosed. The duty only requires a departure from this position if a judge, in unilaterally undertaking a relevance test of any material interests, considers it necessary. Clearly, a judge's introspection determines whether an interest is disclosed. The foregoing psychological analysis portrayed the cognitive limitations associated with self-assessment, which may lead to an overly conservative approach to disclosure. Judges may unduly perceive themselves to able to detach personal or professional interests from a dispute and adjudicate with an impartial mind. In doing so, judges may also attribute their perceived abilities to the public to conclude that disclosure is unnecessary. Moreover, John Leubsdorf found that the

\footnotetext{
${ }^{137}$ McCoy, above n 14, at 335 (emphasis added).

138 "Guidelines for Judicial Conduct", above n 44, at [41]-[45].

139 Register of Pecuniary Interests Bill 2010 (240-1). See generally: Justice and Electoral Committee Register of Pecuniary Interests of Judges Bill (21 February 2014); Law Commission Review of The Judicature Act 1908: Towards a New Courts Act (NZLC R126, 2012); Law Commission Towards a New Courts Act $-A$ register of judges' pecuniary interests? (NZLC IP21, 2011).
} 
"appearance [of bias] test invites judges to rest on appearance, instead of looking deeper [during introspection]". ${ }^{140}$ Leubsdorf identified that inadequate disclosure is, in part, due to "systematic inaccuracy caused by unconscious leanings not removable by introspection". ${ }^{141}$

To minimise any such limitations and encourage disclosure, the author hypothesises that the existing negative disclosure duty should be framed more positively with a softer starting position. Currently, the strong emphasis on impartiality as the base point from which disclosure is made may create some disclosure inertia in judges. If a more party-oriented starting point is adopted, less emphasis may be placed on judicial introspection. For example, if a judge readily discloses any potentially conflicting interests before unilaterally undertaking a materially or relevance test of the interests, the possibility of systematic inaccuracy in introspection may be reduced. It is envisaged that this approach will widen the ambit of disclosure and the onus that was previously on a judge's introspection will partly be shifted to the parties, which should limit the scope for misjudgement. Although wider disclosure may delay proceedings, the time that may be saved from minimising the possibility of a material interest being subsequently discovered and the ensuing potential for wasted litigation is significant. Moreover, with increased disclosure and transparency, litigants' trust in judges and their neutrality may be bolstered.

\section{$2 \quad$ Process of questioning an interest and filing a recusal motion}

A formal and uncomplicated procedure for litigants to file recusal motions should be instilled. Simply raising concerns via notice to the court's Registrar or via an originating application does little to explicitly recognise litigants' right to question a judge's impartiality. A specific avenue to file a recusal motion, similar to that of an interlocutory appeal, should be sufficient and not overly burdensome to remedy the lack of clarity. Recognising questions of partiality as a standard part of court proceedings may go some way to normalising the practice. As a result, the trepidation litigants may harbour of provoking a judge by questioning an appearance of partiality and the corollary stigma that judges may feel when their impartiality is questioned is likely to be reduced.

Further, a recusal motion should have to be brought as soon as practically possible after a relevant interest is disclosed. The complexity of the interest or the subsequent questioning of the judge that a party may have to undertake will affect the practicality of how soon a recusal motion can be brought. The existing implied waiver protocol

\footnotetext{
${ }^{140}$ John Leubsdorf "Theories of Judging and Judge Disqualification" 62(2) New York University Law Review 237 at 278.

${ }^{141}$ Leubsdorf, above n 140, at 262.
} 
adequately covers this. If material detail regarding a judge's potentially conflicting interest subsequently arises, the implied waiver will not apply and parties will be entitled to file a recusal motion despite the delay. This is intended to not only minimise the possibility of wasted litigation, but also to promote proper disclosure of interests as partial disclosure may perpetuate a reasonable apprehension of bias if the judge is later found to be withholding material information.

\section{B An Impartial Arbiter}

The fallacy of a challenged judge being in the best position to assess a conflict of interest is clear. ${ }^{142}$ The New Zealand judiciary has attempted to lessen this untenable position by suggesting that "in cases of uncertainty it may be desirable for the judge to discuss the matter with the relevant head of jurisdiction or another judge." ${ }^{143}$ Likewise the Court of Appeal Recusal Guidelines state "where the issue is not clear cut, the judge should consult ... with other members on the panel". ${ }^{144}$

However, the author opines that consultation with other judges is insufficient for three reasons. First, it can be difficult for judges that are not well versed in the factual matrix of a case to be able to provide reliable counsel ad hoc, particularly when they are unlikely to have the benefit of the motioning party's views to reconcile the challenged judge's views. ${ }^{145}$ Second, consultation may be impractical in trial courts where a single judge sits on a case and other judges on the court may be preoccupied with cases they are sitting on. Third, any such consultation is confidential. Parties may have no knowledge that a challenged judge has consulted with their colleagues, let alone the content of any consultations. Thus, confidentiality is unlikely to further the appearance of justice.

To resolve this preeminent procedural shortcoming, recusal motions need to transferred to and decided by an independent judge. ${ }^{146}$

\footnotetext{
${ }^{142}$ See Part V(E).

143 "Guidelines for Judicial Conduct", above n 44, at [29].

144 "Court of Appeal Recusal Guidelines", above n 56, at [2(b)].

${ }^{145}$ If a challenged judge wishes to consult a potentially disqualifying interest with another judge in a trial court, the judge being consulted will not be informed of the facts of the interest or the case. The situation is different in an appellate court where a panel of judges will be sitting. Here, a challenged judge may be able to consult with the other panel members in a more informed manner as they will presumably be versed in the facts of the case.

${ }^{146}$ When a recusal motion is brought against a judge, their credibility is at stake. Accede to the motion too readily, for example when a fair-minded lay observer would not reasonably apprehend any apparent bias, and litigants may think the judge is "soft" or inept at detaching personal interests. Conversely, if a challenged judge rejects the recusal motion, they are vulnerable to criticism of their impartiality and of course, to a subsequent appeal.
} 
This paper proposes that once a litigant files a recusal motion, an independent judge should be called in to hear the motion and conduct the necessary proceedings. ${ }^{147}$ In a trial court, such as the High Court, a motion should be transferred to a disinterested colleague from the same registry as the challenged judge. A robust method of selecting who that independent judge is will need to set up. One possibility is to form a standing recusal committee in each registry consisting of two or three judges, depending on the size of the registry, that rotate every six to twelve months. If it is impractical for a judge on a standing committee to hear a recusal motion, the next judge due to sit on the committee should be summoned. Of course, the independent judge to whom a motion is transferred can also recuse themselves sua sponte if they cannot, or appear to not be able to, bring an impartial mind to adjudicate the motion.

In an appellate court, such as the Court of Appeal, where there is a panel of judges, the other members of the panel should hear the motion. The challenged judge should not sit on the panel whilst the other panel members hear the motion. Likewise, in a court of last instance, such as the Supreme Court, where the court sits as a whole, the remaining members of the court should hear the motion without the challenged judge sitting on the panel. In the event of a split decision, the head of the relevant court should rule on the matter. This will not undermine the validity of proceedings because courts of final instance can often hear procedural matters without a full quorum. ${ }^{148}$ To dampen litigants' fears about a judge taking offence to being challenged, the party submitting the recusal motion should be anonymous. ${ }^{149}$ To ensure anonymity, all submissions should be made to the Registrar in writing, who will then pass them on to the disinterested judge. Oral hearings would reveal the complainant to the judge and so the proceeding should wholly occur in writing.

Under this regime, judges will still be able to recuse themselves sua sponte. Although this may seem counterintuitive to the idea of having an independent adjudicator, it should not compromise the process. If a judge perceives that an interest may raise a reasonable apprehension of bias, it is likely that an independent judge would come to a similar conclusion. Enabling the challenged judge to conduct this prima facie assessment saves court resources and limits delays in proceedings.

The prescriptive nature of the proposed transfer regime reflects the desire for harder rules that provide the bench and litigants with more certainty and guidance. It also

\footnotetext{
${ }^{147}$ Proceedings in a recusal motion could include affidavits from the applicant and the judge, as well as an articulation of both parties' views.

${ }^{148}$ Supreme Court Act, s 28.

${ }^{149}$ See Part VI(A) for discussion regarding the fear litigants may face in questioning a judge's impartiality due to the potential for subsequent retribution by the judge.
} 
helps to bring judicial recusal in line with other civil procedures that involve formal processes.

\section{Positive Externalities of an Independent Judge: Adversary; Reasoned Decisions; and Precedent}

Transferring a recusal motion to an independent judge enables an adversarial process, reasoned decisions and precedent to develop.

\section{$1 \quad$ Adversarial process}

Without having to adjudicate a recusal motion, a challenged judge is in a more practical position to offer their arguments for continuing to sit on a case. This should lead to more informed considerations of whether an apprehension of bias arises because a challenged judge can contextualise the interest in a manner that is currently missing due to an absence of adversarial process.

\section{$2 \quad$ Reasoned decisions generating precedent}

An independent judge adjudicating a recusal motion is well equipped to reconcile the arguments of a challenged judge and a complainant according to law. In doing so, the judge should articulate their reasoning. Judges who recuse themselves sua sponte should also be required to provide reasons for their decision to not sit on a case. This is particularly important in light of the lopsided recusal precedent that is currently available. Developing a comprehensive body of precedent will not only enhance the uniformity of recusal adjudication but also provide guidance and predictability to litigants with regards to the types of interests that may justify recusal.

\section{Procedural Reform: A Critique}

In contemplating the proposed reform, there were a number of options that were foregone to come to the regime that has been set out. The following section will address potential drawbacks of the proposed reform as well as exploring some alternatives that were considered, but not adopted.

\section{A Concerns with Transferring Recusal Motions to an Independent Judge \\ $1 \quad$ Practical concerns}

Increased pressure on already stretched judicial resources is the practical concern with transferring recusal motions to independent judges. Unlike a challenged judge, an 
independent judge will require time to become accustomed with the interest in issue. The proposed disclosure regime may go some way to minimising the time an independent judge requires to fully discover the facts as all relevant interests should be disclosed at first instance. While an independent judge considers a recusal motion, the cases he or she is sitting on at the time will need to be adjourned. Thus, holding all else equal, the average length of all cases, whether they involve a recusal motion or not, is prima facie likely to increase.

While undoubtedly a real concern, procedural delays can be easy to overstate, particularly when the counterfactual is not considered. A transfer to an independent judge will only occur if a recusal motion is filed; there will be no increased delay relative to the status quo if a judge recuses themselves sua sponte. Further, a judge's ability to synthesise fact and law to come to an efficient solution should not be underestimated; judges are well trained to undertake this task - it is their job. An argument could also be made that parties may be less inclined to appeal the dismissal of a recusal motion made by an independent judge when compared to a dismissal made by a challenged judge. ${ }^{150}$ It is difficult to quantify the increased resource requirements and procedural delays of transferring recusal motions to independent judges. No common law jurisdictions employ this procedure. Although it may be inaccurate to attempt to draw meaningful conclusions regarding an undue increase in demand for court resources ex ante, one commentator, when contemplating a similar regime to what has been proposed here, suggested that, on balance, "the overall administrative burden in fact might not increase". ${ }^{151}$

\section{$2 \quad$ Principled concerns}

Cognitive studies have established that judges, like everyone else, are susceptible to unconscious biases that hinder their ability to self-adjudicate. ${ }^{152}$ Bearing in mind that an independent judge to whom a recusal motion will be transferred is a colleague of the challenged judge, is he or she going to be any more effective in applying the fair-minded lay observer test than the challenged judge? Akin to a litigant's hesitancy when making a recusal motion, an independent judge may also be cautious in affirming a recusal motion for fear of offending their colleague. ${ }^{153}$ Additionally, Geyh theorised that transferring a

\footnotetext{
${ }^{150}$ Seth E Bloom "Judicial Bias and Financial Interest as Grounds for Disqualification of Federal Judges" (1985) 35 Case Western Reserve Law Review 662 at 697.

${ }^{151}$ Bloom, above n 150, at 697.

${ }^{152}$ See Part V(E) for discussion on the psychology of self-adjudication.

153 While this finding should not be taken at face value due to contrast in legal systems between New Zealand and the United States, empirical research from the United States provides an interesting insight into judges' psychology of assessing their colleagues' impartiality. Jeffrey M Shaman and Jona Goldschmidt Judicial Disqualification: An Empirical Study of Judicial Practices and Attitudes (American Judicature Society, Nashville, 1995) at 70: "under the same circumstances judges ... [have a] stronger tendency to disqualify themselves than to recommend disqualification of a colleague". It is not
} 
recusal motion to an independent judge may have a detrimental effect on a challenged judge's credibility because "assigning disqualification motions to a different judge implies that the target judge cannot be trusted to rule impartially". 154

In acknowledging that these are cogent concerns about the (in)efficacy of an independent judge adjudicating a recusal motion, it is pertinent to return to first principles to fully address their validity. Impartiality is assessed from the perspective of a fairminded lay observer. It reflects Lord Hewart CJ's well-cited dictum of justice being seen to be done. Thus, notwithstanding the merits, or lack thereof, of an independent judge's decision, the public's perception of how that decision was made is of utmost importance. Accordingly, the public is more likely to think that a decision is made impartially if it is made by an independent judge as opposed to being self-adjudicated by the challenged judge.

Furthermore, judges are accustomed to disagreeing with one another and having colleagues critique their judgments. For example, it is commonplace for judges to dissent from the majority in appellate courts. Similarly, it is standard practice for an appellate court to overturn a trial court's decision. Having a decision overturned is arguably more critical of a judge than a finding of apparent bias because the former speaks to a judge's competency and aptitude to adjudicate. While genuine questions remain about the actual benefits of transferring a recusal motion to an independent judge, the perceived benefits should be sufficient to justify transferring recusal motions to independent judges.

\section{B Alterations to the Proposed Reform}

\section{$1 \quad$ When should a recusal motion be transferred to an independent judge?}

The proposed reform suggests that all recusal motions should be heard by an independent judge. Contrarily, Hammond envisages that, at first instance, all recusal motions should be determined by the challenged judge, ${ }^{155}$ only if a recusal motion is dismissed should it be transferred to an independent judge or, in an appellate court, to the other members of the sitting panel. ${ }^{156}$ Interestingly, in the latter situation, Hammond saw no difficulties in a challenged judge continuing to sit on a panel and hear the recusal motion even after dismissing it at first instance. ${ }^{157}$ Presumably, Hammond was addressing resource

inconceivable that New Zealand judges may think in a similar vein, especially considering the small size of New Zealand's jurisdiction, judges are more likely to be well acquainted with each other than they are in the United States.

${ }^{154}$ Geyh, above n 8, at 728.

${ }^{155}$ Hammond, above $\mathrm{n} 25$, at 165, appendix E.

156 Hammond, above n 25, at 148-149.

${ }^{157}$ Hammond, above n 25, at 148-149. 
constraints in suggesting this method of transferring recusal motions. While this is likely to cause less delays and require less resources than transferring all recusal motions to independent judges at first instance, principled concerns, similar to those addressed earlier, arise. $^{158}$

By maintaining self-adjudication at first instance, the shortcomings of the current recusal regime will continue to prevail. ${ }^{159}$ Further, a challenged judge may feel that their credibility is harmed if their decision to dismiss a recusal motion is subsequently overturned by an independent judge - a situation that would be avoided if the recusal motion is transferred to an independent judge at first instance. Most importantly, the cognitive limitations of self-judging and the accompanying marginalisation of public confidence will continue to undermine the judicial recusal process. Accordingly, the resources that would be saved by adopting this quasi-independent recusal regime need to be balanced with the principled compromises that it entails.

\section{$2 \quad$ Procedural posturing}

While the heightened disclosure obligation, standardised procedure for litigants to file recusal motions, increased scrutiny on that motion by an independent judge and a reasoned decision has its benefits, it may be subject to abuse. Primarily, litigants may file frivolous motions simply to elongate the proceeding and squeeze the other party's financial resources. To disincentive procedural abuse for private benefit, the proposed reform has some safeguards. To minimise delay, an implied waiver will continue to apply to prevent recusal motions being made in an untimely manner. Moreover, if an independent judge deems a recusal motion to be wholly aimed at delaying the proceeding rather than a genuine question of a judge's potentially disqualifying interest, costs for the time the recusal motion took to determine may be awarded for the party that did file the motion to ensure that they are not financially harmed by a litigant's procedural tactics.

\section{$3 \quad$ Peremptory recusal}

To avoid potential confusion, uncertainty and inconsistency, some commentators have gone beyond procedural reform to help assess recusal motions to a system of peremptory recusal. ${ }^{160}$ Under a peremptory recusal regime, upon an allegation of partiality being made, the case is automatically transferred to a new judge without the need to find apparent bias. ${ }^{161}$ Each party is limited to the opportunity to make one claim. ${ }^{162}$

\footnotetext{
${ }^{158}$ See Part VIII(A)(2).

${ }^{159}$ See Part VI.

${ }^{160}$ Frost, above n 102, at 587, n 262.

161 Frost, above n 102, at 587.

${ }^{162}$ Frost, above n 102, at 587.
} 
Proponents of a peremptory system cite its simplicity, expediency and the benefit in not requiring an application of the indeterminate apparent bias test. It is based upon the idea that impartiality does not lie on a spectrum; one is either impartial or partial. Thus, when there is even an allegation of partiality, the public may question the judge's impartiality and, since impartiality revolves around public perception, the damage to the public's perceptions of impartiality has been done. A peremptory recusal regime is undeniably simpler than applying the apparent bias test to a judge's potentially conflicting interest. However, it also has major shortcomings.

A peremptory recusal regime can lead to a case being reallocated twice to two new judges. While any ensuing delays need to be considered against any delays that arise from transferring a recusal motion to an independent judge, there is potential for the delays to be substantial. Further, without an articulation of the interest in question, no guidance is provided to ensure that the new judge to whom the case may be transferred will be any less partial than the recused judge. By automating judicial recusal, the number of recusals is likely to increase, which may harm public confidence in the judiciary. Frost recognised the dangers of too much judicial recusal when she stated that "increased frequency of disqualification ... might arguably tend to undermine public confidence in the judiciary by disparaging the general impartiality of judges." 163 Thus, this paper opines that the peremptory recusal regime's practical and principled flaws outweigh its simplicity and expediency.

\section{Focus on Substance Rather than Procedure}

This paper has looked to procedure as a means of fostering judicial impartiality and in turn maintaining the public's confidence in the judiciary. Faced with the reality that reasonable minds can differ in determining reasonable apprehensions of bias, principled procedural safeguards, rather than supplementary substantive articulation, have been used in an attempt to curb inconsistencies and increase transparency and uniformity. ${ }^{164}$ Professor Stempel, while accepting that there is a need for greater procedural

\footnotetext{
${ }^{163}$ Frost, above n 102, at 747.

${ }^{164}$ See for example: Philip Bryden and Jula Hughes "The Tip of the Iceberg: A Survey of the Philosophy and Practice of Canadian Provincial and Territorial Judges Concerning Judicial Disqualification" 48 Alberta Law Review 569. Although this is a Canadian survey, the Canadian jurisdiction similarly looks to a reasonable apprehension of bias in deciding recusal motions. The authors proposed hypothetical scenarios to which the surveyed judges responded by stating whether they would recuse themselves or not or whether they were unsure. In over half of the scenarios, no one answer attracted the support of a majority of respondents.
} 
mechanisms, suggests that "the legal system and the body politic needs to accept an updated, 'post-modern,' approach to operationalising the appearance standard". ${ }^{165}$

Stempel's proposition was based on the contradiction between the theoretical base for the appearance standard requiring "almost universal [public] agreement that the appearance of impartiality standard has been breached" 166 and the reality of a "modernpost-modern world of diverse communities, differing ideologies, varied background, and competing ideologies" 167 that prevents universal consensus. He opined that recusal law is unduly conservative - and in fact weak - if broad agreement is necessary before a finding of partiality is made. ${ }^{168}$ To remedy this, Stempel set out a need to "expand [the appearance standard] to match the reality of illusive consensus". ${ }^{169}$ The importance of substance did not allude Geyh either, as he posited the need for the legal profession and the public to "share a basic understanding of what constitutes an appearance of impartiality". 170

This paper acknowledges the merits of Stempel's argument. In the interests of space, the focus of this paper has been on procedural reform because the author hypothesises that it is the area that is in most need of attention. This sentiment is shared by other interested parties. For example, when investigating the way forward for judicial recusal, the Law Commission identified that "there is widespread agreement amongst commentators that the least satisfactory aspect of current recusal law lies in the processes adopted, or more accurately, not expressly formulated by courts." ${ }^{171}$ The Law Commission went further in concluding that they consider "the best way to deal with potential judicial conflicts of interest is to have clear, robust and well-publicised rules and process for recusal." 172 Moreover, principled procedure can aid substantive clarity. Reasoned decisions build a wealth of precedent that may provide the legal profession, and eventually the public, with the necessary clarity to harmonise their understanding of partiality. As Frost deduced, "altering the substance of the recusal standards has proven to be an ineffective method of reforming [judicial recusal law]". ${ }^{173}$

\footnotetext{
165 Stempel, above n 123 , at 808 .

166 Stempel, above n 123, at 808 .

${ }^{167}$ Stempel, above n 123 , at 810 .

168 Stempel, above n 123 , at 810 .

${ }^{169}$ Stempel, above n 123, at 811. See at 811-823 for Stempel's take on operationalising a minority recusal standard.

${ }^{170}$ Geyh, above n 8, at 676.

${ }^{171}$ Law Commission Towards a New Courts Act - A register of judges' pecuniary interests?, above n 139, at [2.23]; Hammond, above n 25, at 72; New Zealand Law Society "Submission to the Justice and Electoral Committee on the Register of Pecuniary for Judges Bill 2010" at 13: "current practices are not well understood by litigants and counsel, and they are inconsistently applied".

${ }^{172}$ Law Commission Review of The Judicature Act 1908: Towards a New Courts Act, above n 139, at [6.58].

${ }^{173}$ Frost, above n 102, at 534.
} 


\section{Reform: A Solution in Search of a Problem?}

Following the resignation of Wilson J, Dr Kennedy Graham MP introduced the Register of Pecuniary Interests of Judges Bill to parliament. ${ }^{174}$ As alluded to earlier, the Bill requires judges to periodically disclose their pecuniary interests in a public register. ${ }^{175}$ Although it looked to reform by way of disclosure rather than procedure or altering the substantive test for bias, the legal profession vehemently opposed it. The Chief Justice (on behalf of the New Zealand judiciary), the New Zealand Law Society and the New Zealand Bar Association all stated that a pecuniary interests register is unwarranted and unnecessary. ${ }^{176}$ They, along with the Law Commission and the Justice and Electoral Committee, cited there was "no evidence of a lack of public confidence in the judiciary" ${ }^{177}$ to justify reform.

This paper does not refute that the New Zealand judiciary enjoys a high level of public confidence. However, the author suggests that it can be misleading to assume that the end - with the end being public confidence in an impartial judiciary - justifies the means - with the means being judicial recusal law. It is worth noting a speech delivered by New Zealand's former Chief Justice, Sir Thomas Eichelbaum, where he stated that the judiciary "[is not] a bastion which will suddenly fall. The danger lies in the risk of an insidious weakening of the castle foundations over a period of time". ${ }^{178}$ That risk, in the recusal context, is a reoccurrence of a publicly condemnable conflict of interest between a judge and a party. Furthermore, the foregoing principled analysis belies suggestions that the prevailing judicial recusal regime is sufficient and that reform is unnecessary.

\section{Saxmere Revisited, Following Reform}

Following the foregoing analysis of judicial recusal law, it is pertinent to contextualise the mismatch between process theory and the realities of recusal procedure by returning to the Saxmere saga. In doing so, the author looks to substantiate his hypothesis that:

\footnotetext{
${ }^{174}$ Register of Pecuniary Interests Bill 2010 (240-1).

${ }^{175}$ See generally: Law Commission Towards a New Courts Act - A register of judges' pecuniary interests?, above n 139; Law Commission Review of The Judicature Act 1908: Towards a New Courts Act, above $\mathrm{n}$ 139; Justice and Electoral Committee, above n 139.

${ }^{176}$ See generally: New Zealand Bar Association "Submission to the Justice and Electoral Committee on the Register of Pecuniary for Judges Bill 2010"; New Zealand Law Society "Submission to the Justice and Electoral Committee on the Register of Pecuniary for Judges Bill 2010"; Sian Elias CJ (on behalf of the judiciary) "Submission to the Justice and Electoral Committee on the Register of Pecuniary for Judges Bill 2010".

177 Justice and Electoral Committee, above n 139, at 3.

178 Thomas Eichelbaum, former Chief Justice of New Zealand "Judicial Independence Revisited" (Neil Williamson Memorial Lecture, Christchurch, 13 August 1997).
} 
one, a lack of procedural safeguards may have contributed to the controversy; and two, that had procedural safeguards, namely the procedures proposed in this paper, been in place, the controversy could have been mitigated, if not avoided

\section{A Disclosure}

Disclosure, or lack thereof, played a major role in the Saxmere saga. While Wilson J's attempted disclosure, being at the beginning of the proceeding, was timely, it was in private and the details revealed were imprecise. If Wilson $\mathrm{J}$ had followed court guidelines, the disclosure should have been made through the court's Registrar. The author posits that the soft nature of the existing disclosure obligations, with its negatively framed duty and heavy emphasis on introspection, may have been a material cause of the minimal disclosure.

Beginning with a strong assumption of impartiality from which to introspect whether the Rich Hill business association should be disclosed, Wilson J unilaterally undertook an internal assessment of the interest's relevance and materiality to the proceeding. Notwithstanding that he clearly saw sufficient relevance to attempt disclosure, the method perpetuates the cognitive difficulties he may have faced, like everyone would have, in assessing his own interests - defined earlier as a "systematic inaccuracy caused by unconscious leanings not removable by introspection". ${ }^{179}$ By starting from a softer assumption of impartiality and shifting the emphasis from introspection to a more positively framed and open disclosure duty, the author opines that the proposed disclosure regime may have led to a more forthright revelation by Wilson $\mathrm{J}$ of the interest at first instance. The onus to consider whether a reasonable apprehension of bias arises shifts to the parties, namely Saxmere, rather than remaining a part of Wilson $\mathrm{J}$ 's introspection. Disclosing in open court would have minimised the uncertainty and negative connotations associated with a private phone call. Further, had the particulars of the business relationship been disclosed, namely that Rich Hill was an active company to which Wilson $\mathbf{J}$ and Galbraith had contributed disproportionate levels of capital, the implied waiver of failing to file a recusal motion in a timely manner would have precluded Saxmere's ability to appeal to the Supreme Court on that basis.

To emphasise that the Saxmere saga was not a one-off failure by Wilson $\mathrm{J}$ to disclose his business relationship with Galbraith, it is helpful to analyse subsequent cases in which the two appeared on the bench and bar, respectively. Of the four cases where this scenario transpired before the Saxmere No 2 appeal was made, only once did Wilson

${ }^{179}$ Leubsdorf, above n 140, at 262. 
$\mathrm{J}$ disclose to all counsel his business relationship with Galbraith. ${ }^{180}$ His rationale for nondisclosure was that he "he did not see it as [a] conflicting [interest]"181 and in any event he was confident that all counsel in the proceedings already knew his business relationship with Galbraith. Without undertaking to validate Wilson J's latter assumption of counsels' knowledge, the author views the former rationale as a personification of the current disclosure duty's frailties.

While it is uncertain whether Wilson $\mathbf{J}$ would have disclosed more adequately under the proposed disclosure regime, the author hypothesises that at the very least, disclosure would have been fuller than it was under the existing regime.

\section{B Filing a Recusal Motion}

In light of Wilson J's scant disclosure regarding his business relationship with Galbraith, Saxmere may have wanted to inquire further about the relationship to feel more comfortable that it did not raise an apprehension of bias. However, Saxmere may have been hesitant to undertake any additional inquiries or file a recusal motion for fear of annoying Wilson $\mathbf{J}$ - which in hindsight may have been likely because Wilson $\mathbf{J}$ was clearly of the view that the business relationship did not raise a reasonable apprehension of bias.

The existing informal and ad hoc process for raising questions of partiality reasonably invites some trepidation from litigants. Under the proposed regime, making inquiries to better understand a disclosed interest and to guide the decision whether to file a recusal motion will be framed as another common part of civil procedure, similar to interlocutory appeals. Institutionalising this practice should lessen litigants' fears of reprisal. Thus under the proposed regime, Saxmere may have been more inclined to question Wilson $\mathrm{J}$ further about the business relationship and subsequently file a recusal motion. This may have minimised, if not eliminated, the subsequent appeals.

\section{An Independent Judge and its Corollary Benefits}

With more disclosure, Saxmere presumably would have filed a recusal motion considering that its grounds of appeal in Saxmere No 2 were based on imperfect knowledge of the potentially conflicting business relationship. Existing recusal procedure would have left Wilson $\mathrm{J}$ to adjudicate the recusal motion. Although he may have discussed the recusal motion with the other two judges on the panel, William Young

\footnotetext{
180 Judicial Conduct Commissioner, above n 11, at 30-31, appendix 1.

${ }^{181}$ Judicial Conduct Commissioner, above n 11, at 30-31, appendix 1.
} 
$\mathrm{P}$ and Glazebrook $\mathrm{J}$, the decision would have been his to make. As discussed, judges face cognitive difficulties when self-adjudicating and the prevailing practice is unlikely to foster the public's confidence in an impartial decision being made. Under proposed reform, the recusal motion would have been decided by William Young P and Glazebrook $\mathbf{J}$. The transfer would have facilitated an adversarial process whereby Wilson $\mathbf{J}$ could have responded to the motion with his views as to why the business interest does not warrant recusal. Even if William Young $\mathrm{P}$ and Glazebrook $\mathrm{J}$ arrived at a similar conclusion to Wilson $\mathrm{J}$ and dismissed the recusal motion, the public is likely to be more accepting of a decision made by independent judges rather than one made by a challenged judge.

Even if the recusal motion was not transferred and was left to be adjudicated by Wilson $\mathrm{J}$, if a comprehensive body of precedent had been available, he would have had more guidance from which to make a decision. Presumably, the precedent would have indicated that the unequal nature of the business relationship and Wilson J's indebtedness to Galbraith warranted a finding similar to that the Supreme Court in Saxmere No 3 came to: that a reasonable apprehension of bias arose and Wilson $\mathrm{J}$ should not have sat on the case. Requiring a reasoned decision not only reduces the chance of a judge making a hasty and unconsidered decision to sit or recuse themselves, it builds a body of precedent to better guide judges and litigants alike.

Precedent would have been particularly helpful for Wilson J, who, as a judge, was very inexperienced at the time of the case. ${ }^{182}$ Evidently, judicial conduct guidelines did not provide the necessary guidance to Wilson $\mathrm{J}$ as he had, but did not take, the opportunity to discuss the extent of the potentially conflicting interest with William Young $\mathrm{P}$ and Glazebrook J. ${ }^{183}$ Commentators may postulate that Wilson J's inexperience on the bench played a determinative factor in his conduct. However, his continued failure to disclose the interest in subsequent cases involving Galbraith weakens this theory. Significantly, Wilson $\mathbf{J}$ sat on the panel that adjudicated the Muir case which suggests that he would have had intimate knowledge of the law and protocol relating to recusal and yet he failed to adequately apply this knowledge in practice. ${ }^{184}$ This highlights that despite being well

\footnotetext{
182 Judicial Conduct Commissioner, above n 11, at [34].

183 The 2013 Judicial Conduct Guidelines referred to in this paper are a revised version of a set of guidelines that were initially approved by New Zealand judges in 2003. Thus, at the time of Saxmere No 1, Wilson J would have had a set of judicial conduct guidelines at his disposal, as well as the Judges' Benchbook, which is not public available.

${ }^{184}$ Muir v Commissioner of Inland Revenue, above n 2. As mentioned, the Supreme Court in Saxmere No 2 affirmed the Court of Appeal's approach in Muir, which brought New Zealand in line with Australia and the United Kingdom's judicial recusal laws.
} 
acquainted with judicial recusal law, its soft and imprecise nature can lead to inconsistent application.

The foregoing application of proposed reform to the Saxmere saga illustrates the real remedial potential of proper process in the area of recusal. The parties would have saved a substantial amount of costs that had to be incurred to relitigate the case, not to mention the time delay. Most importantly, the transparent, structured and principled nature of the proposed reform may have averted what the Hon David Parker described as: "a very sad day when we have this taint on our judiciary - and it is a taint. We have to acknowledge it is a taint." 185

\section{Conclusion}

Judicial impartiality is almost assumed and thus rarely features at the forefront of the legal profession's mind. However, the Saxmere saga thrust it into the limelight with a series of events that culminated in the resignation of a Supreme Court justice: Wilson J. Now that the dust has settled on the controversy and the intense public scrutiny has receded, it is pertinent to question the status quo and investigate the potential cause of the events and, more importantly, whether measures need to be taken to prevent another such occurrence.

This paper has adopted a principled approach to analysing judicial recusal law in New Zealand, with a particular focus on procedure. In doing so, a mismatch between process theory and the reality of haphazard self-regulation highlighted the procedural shortcomings of the current recusal paradigm. To remedy this, the author applied aspects of process theory to reform judicial recusal procedure and bring it in line with the general civil litigation process in New Zealand. The proposed reform instils some fundamental practices that are presently absent in recusal procedure. To contextualise the paper's findings, the author revisited the Saxmere saga to: first, posit that a lack of procedural safeguards may have contributed to the saga; and two, to suggest that had the procedural safeguards proposed by this paper been in place, the controversy could have been mitigated, if not avoided.

Looking back at Sian Elias CJ's statement that "today respect for courts ... has to be earned and re-earned", ${ }^{186}$ this paper's analysis has questioned judicial recusal law's ability to do just that. To apply the Caesar's wife's principle, "it is not enough that they [judges] give fair, impartial and reasoned judgments. They must bend over backwards to

\footnotetext{
185 (9 November 2010) 668 NZPD 15085.

${ }^{186}$ Elias, above n 10.
} 
JUDICIAL RECUSAL IN NEW ZEALAND: LOOKING TO PROCEDURE AS THE PRINCIPLED WAY FORWARD

be seen to be doing so". ${ }^{187}$ While the New Zealand judiciary does enjoy the public's confidence, it should not rest on its laurels and view the Saxmere saga as an exception to an otherwise satisfactory judicial recusal regime. It should serve as a wakeup call that significant deficiencies in recusal law exist. In the author's opinion, procedural reform holds considerable promise in providing a robust and principled basis from which judicial impartiality can be - and most importantly, can be seen to be - maintained.

${ }^{187}$ Andrew Geddis "No more buddy buddy, no more messing around" (2010) Pundit <http://pundit.co.nz>. The Caesar's wife principle states that one must be completely above suspicion. 
JUDICIAL RECUSAL IN NEW ZEALAND: LOOKING TO PROCEDURE AS THE PRINCIPLED WAY FORWARD

\section{Bibliography}

\section{A Primary Material}

$1 \quad$ Cases

(a) New Zealand

Muir v Commissioner of Inland Revenue [2007] NZCA 334, [2007] 3 NZLR 495.

Muir v Judicial Conduct Commissioner [2013] NZHC 3507.

Saxmere Co v Wool Board Disestablishment Co [2009] NZSC 72, [2010] 1 NZLR 35 [Saxmere No 2].

Saxmere Co v Wool Board Disestablishment Co [2009] NZSC 122, [2010] 1 NZLR 76 [Saxmere No 3].

Wilson v Attorney-General [2011] 1 NZLR 399.

Wool Board Disestablishment Co v Saxmere Co [2007] NZCA 349, [2007] BCL 885 [Saxmere No 1].

(b) Australia

Aussie Airlines Pty Ltd v Australian Airlines Pty Ltd [1996] 65 FCR 215, (2006) 135 ALR 753.

Ebner v Official Trustee in Bankruptcy (2000) 205 CLR 337.

Porter v Magill [2002] 2 AC 357.

Re JRL; ex parte CJL (1986) 161 CLR 342.

Webb v R (1994) 181 CLR 41.

(c) United Kingdom

Helow v Secretary of State for the Home Department [2008] 1 WLR 2416.

Locabail (UK) Ltd v Bayfield Properties Ltd [2000] QB 451.

Metropolitan Properties Co (FGC) v Lannon [1969] 1 QB 577 (CA). 
JUDICIAL RECUSAL IN NEW ZEALAND: LOOKING TO PROCEDURE AS THE PRINCIPLED WAY FORWARD

$R v$ Bow Street Metropolitan Stipendiary Magistrate, ex parte Pinochet Ugarte (No 2) [2000] AC 119.

$R v$ Gough [1993] AC 646.

$R v$ Sussex Justices, ex parte McCarthy [1924] 1 KB 256.

$2 \quad$ New Zealand Legislation

Bill of Rights Act 1990.

Constitution Act 1986.

Judicature Act 1908.

Judicial Conduct Commissioner and Judicial Conduct Panel Act 2004.

Oaths and Declarations Act 1957.

Sentencing and Parole Reform Act 2010.

Supreme Court Act 2003.

$3 \quad$ Bills

Register of Pecuniary Interests Bill 2010 (240-1).

$4 \quad$ Parliamentary debates (Hansard)

(9 November 2010) 668 NZPD 15085.

$5 \quad$ International material

The Universal Declaration of Human Rights, GA Res 217A, III UN GAOR A/810 (1948).

\section{B Secondary Material}

$1 \quad$ Texts

Alexander M Bickel The Lease Dangerous Branch: The Supreme Court at the Bar of Politics (2nd ed, Yale University Press, New Haven, 1986).

Grant Hammond Judicial Recusal: Principles, Process and Problems (Hart Publishing, Portland, 2009).

Harry Woolf, Jeffrey Jowell and Andrew Le Sueur De Smith's Judicial Review (6th ed, Sweet \& Maxwell, London, 2007). 
JUDICIAL RECUSAL IN NEW ZEALAND: LOOKING TO PROCEDURE AS THE PRINCIPLED WAY FORWARD

HP Lee (ed) Judiciaries in Comparative Perspective (Cambridge University Press, Cambridge, 2011).

James Boyd White Heracles' Bow: Essays on the Rhetoric and Poetics of the Law (University of Wisconsin Press, Wisconsin, 1985).

Jeffrey M Shaman and Jona Goldschmidt Judicial Disqualification: An Empirical Study of Judicial Practices and Attitudes (American Judicature Society, Nashville, 1995).

John Locke Second Treatise of Government (Awnsham Churchill, 1690).

J Thibaut and L Walker Procedural Justice: A Psychological Analysis (Lawrence Erlbaum Associates, 1975).

Kevin Burke and Steve Leben Procedural Fairness: A Key Ingredient in Public Satisfaction (A White Paper of the American Judges Association) (American Judges Association, Williamsburg, 2007).

Philip A Joseph Constitutional and Administrative Law in New Zealand (4th ed, Brookers, Wellington, 2014).

Richard E Flamm Judicial Disqualification: Recusal and disqualification of Judges (2nd ed, Banks \& Jordan Law Publishing Co, Berkley, 2007).

Robert H Bork The Tempting of America (Free Press, New York, 1990).

Simon Shetreet The Role of Courts in Society (Martinus Nijhoff Publishers, Dordrecht, 1989).

\section{$2 \quad$ Essays in books}

Gerard McCoy "Judicial Recusal in New Zealand" in HP Lee Judiciaries in Comparative Perspective (Cambridge University Press, 2011) 322.

Philip A Joseph "Appointment, discipline and removal of judges in New Zealand" in HP Lee (ed) Judiciaries in Comparative Perspective (Cambridge University Press, Cambridge, 2011) 66.

Simon Shetreet "Judging in Society: The Changing Role of Courts" in Simon Shetreet The Role of Courts in Society (Martinus Nijhoff Publishers, Dordrecht, 1989) 467. 
JUDICIAL RECUSAL IN NEW ZEALAND: LOOKING TO PROCEDURE AS THE PRINCIPLED WAY FORWARD

Tom R Tyler "Procedural Justice" in Sarat Austin The Blackwell Companion to Law and Society (Wiley-Blackwell, 2004) 435.

\section{$3 \quad$ Journal articles}

Amanda Frost "Keeping Up Appearances: A Process-Oriented Approach to Judicial Recusal" (2005) 53(3) Kansas Law Review 531.

B Robertson "Judicial Ethics" [2010] 121(4) NZLJ 121.

Charles G Geyh "Why Judicial Disqualification Matters. Again" (2011) 30 The Review of Litigation 671.

Christopher J Peters "Adjudication as Representation" (1997) 97(2) Columbia Law Review 312.

Christopher J Peters "Persuasion: A Model of Majoritarianism as Adjudication" (2001) 96(1) Northwestern Law Review 1.

Diane Sivasubramaniam and Larry Heuer "Decision Makers and Decision Recipients: Understanding Disparaties in the Meaning of Fairness" (2007) 44(1) Court Review 62.

Emily Pronin, Daniel Lin and Lee Ross "The Bias Blind Spot: Perceptions of Bias in Self Versus Others" (2002) 28 Personality and Social Psychology Bulletin 369.

Frank B Cross "Decisionmaking in the US Circuit Court of Appeals" (2003) 91(6) California Law Review 1457.

Frederick Schauer "Giving Reasons" (1995) 47 Stanford Law Review 633.

Geoffrey C Shaw "HLA Hart's Lost Essay: Discretion and the Legal Process School" (2013) 127(2) Harvard Law Review 666.

Jeffrey W Stempel "In Praise of Procedurally Centered Judicial Disqualification - and a Stronger Conception of the Appearance Standard: Better Acknowledging and Adjusting to Cognitive Bias, Spoliation, and Perceptual Realities" (2011) 30 The Review of Litigation 733.

John Leubsdorf "Theories of Judging and Judge Disqualification" 62(2) New York University Law Review 237.

John M Greacen "Social Science Research on 'Procedural Justice': What are the Implications for Judges and Courts" (2008) 47 Judges' Journal 41. 
JUDICIAL RECUSAL IN NEW ZEALAND: LOOKING TO PROCEDURE AS THE PRINCIPLED WAY FORWARD

John P Frank "Disqualification of Judges" (1947) 56 YLJ 605.

John R Allison "Ideology, Prejudgment, and Process Values" (1994) 28 New England Law Review 657.

Larry Heuer "What's Just About the Criminal Justice System? A Psychological Perspective" (2005) 13 Journal of Law \& Policy 209.

Note "Disqualification of a Judge on the Ground of Bias" (1927) 41(1) Harvard Law Review 78.

Philip Bryden and Jula Hughes "The Tip of the Iceberg: A Survey of the Philosophy and Practice of Canadian Provincial and Territorial Judges Concerning Judicial Disqualification" 48 Alberta Law Review 569.

Robin Cooke "Fundamentals" (1988) NZLJ 158.

Saskia Righarts and Mark Henaghan "Public Perceptions of the New Zealand Court System: An Empirical Approach to Law Reform" (2010) 12(2) Otago Law Review 329.

Tom R Tyler "Social Justice: Outcome and Procedure" (2000) 35(2) International Journal of Psychology 117.

Tom R Tyler "The Role of Perceived Injustice in Defendants' Evaluations of Their Courtroom Experience" (1984) 18(1) Law \& Society Review 51.

Tom R Tyler "What is Procedural Justice? Criteria Used by Citizens to Assess the Fairness of Legal Procedures" (1988) 22(1) Law \& Society Review 103.

\section{$4 \quad$ Internet materials}

Andrew Geddis "No more buddy buddy, no more messing around" (2010) Pundit $<$ http://pundit.co.nz>.

Sensible Sentencing Trust "About Us" Sensible Sentencing Trust $<$ http://www.sst.org.nz>.

$5 \quad$ New Zealand government material

"Court of Appeal Recusal Guidelines" (June 2013) Courts of New Zealand <www.courtsofnz.govt.nz>. 
JUDICIAL RECUSAL IN NEW ZEALAND: LOOKING TO PROCEDURE AS THE PRINCIPLED WAY FORWARD

"Guidelines for Judicial Conduct" (March 2013) Courts of New Zealand <www.courtsofnz.govt.nz>.

$6 \quad$ Reports

Judicial Conduct Commissioner Decision of the Judicial Conduct Commissioner as to Three Complaints Concerning Justice Wilson (7 May 2010).

Justice and Electoral Committee Register of Pecuniary Interests of Judges Bill (21 February 2014).

Law Commission Review of The Judicature Act 1908: Towards a New Courts Act (NZLC R126, 2012).

Law Commission Towards a New Courts Act - A register of judges' pecuniary interests? (NZLC IP21, 2011).

$7 \quad$ Submissions to the Law Commission and Select Committees

Judicial Conduct Commissioner "Submission to the Justice and Electoral Committee on the Register of Pecuniary for Judges Bill 2010".

New Zealand Bar Association "Submission to the Justice and Electoral Committee on the Register of Pecuniary for Judges Bill 2010".

New Zealand Law Society "Submission to the Justice and Electoral Committee on the Register of Pecuniary for Judges Bill 2010".

Sian Elias CJ (on behalf of the judiciary) "Submission to the Justice and Electoral Committee on the Register of Pecuniary for Judges Bill 2010".

The Council of Chief Justices of Australia "Guide to Judicial Conduct" (March 2007) Supreme Court of Western Australia <www.supremecourt.wa.gov.au>.

WM Wilson QC "Submission to the Law Commission Issues Paper: Towards a new Court Act $-A$ register of judges' pecuniary interests.

$8 \quad$ Media articles

Nicky Hager "Appeal Court Judge Faces a Question of Judgement" The Sunday Star Times (New Zealand, 24 August 2008). 
JUDICIAL RECUSAL IN NEW ZEALAND: LOOKING TO PROCEDURE AS THE PRINCIPLED WAY FORWARD

9 Speeches

Philip Havers and Alasdair Henderson "Recent Developments (And Problems) In the Law On Bias" (Hart Judicial Review Conference, The Cavendish Conference Centre, London, 10 December 2010).

Sian Elias, Chief Justice of New Zealand "Contemporary Issues for Courts Demystifying the Judicial Process" (Conference of Chief Justices of Asia and Pacific 2013, Supreme Court, Singapore, 29 October, 2013).

Thomas Eichelbaum, former Chief Justice of New Zealand "Judicial Independence Revisited" (Neil Williamson Memorial Lecture, Christchurch, 13 August 1997). 